\title{
The Solutionist Ethic and the Spirit of
}

\author{
Digital Capitalism*
}

\author{
Oliver Nachtwey ${ }^{\dagger} \quad$ Timo Seidl $l^{\ddagger}$
}

March 13, 2020

\begin{abstract}
Why do tech elites believe they are the world's greatest do-gooders and why does it matter what they say and (claim to) think? In this paper, we use the concept of the spirit of capitalism to shed light on the ways in which normative beliefs inform and justify the business models of tech companies. We first reconstruct, systematize and operationalize the concept of the capitalist spirit. We then argue that solutionist ideas have become central to the (self-)image of today's tech companies. Solutionism refers to the idea that the use of technologies - by inventive and cunning entrepreneurs - is the royal road to fixing social problems. We use a classification algorithm trained on handcoded documents to empirically trace the relative importance of solutionist vis-à-vis other normative beliefs in three novel text corpora. We find that solutionist ideas are indeed central to the worldview of tech elites, and that they are also gaining ground in the broader tech milieu, although not yet in the normative discourse of capitalism at large. Finally, we theorize and illustrate the motivating, legitimizing, and orienting role of the capitalist spirit. In doing so, we contribute - conceptually, theoretically, and empirically - to the budding debates on the moral embeddedness of economic action and on the nature and trajectory of digital capitalism.
\end{abstract}

Keywords: Spirit of Capitalism, Digital Capitalism, Solutionism, Supervised Learning, Morality, Embeddedness

\footnotetext{
${ }^{*}$ We would like to thank Johannes Truffer, Kemal Yüksel, Jacqueline Kalbermatter, Joshua Klein, Gerhard Lauer, and Nicole Philipp-Jahnke for their incredible help during various stages of this research project. Without them, this paper would not have been possible.

${ }^{\dagger}$ University of Basel, oliver.nachtwey@unibas.ch

${ }_{\ddagger}^{\ddagger}$ European University Institute, timo.seid@eui.eu
} 


\section{Introduction}

After years of almost unadulterated techno-optimism, digital capitalism faces a legitimation crisis. The tech giants, long heralded as agents of capitalist rejuvenation and societal progress, are now the BAADD guys: " $b$ ig, anti-competitive, addictive and destructive to democracy" (The Economist, 2018). Academics and policymakers alike are calling for more regulation, while calling the tech giants out on their harmful, extractive, and monopolistic business practices. Pushback also comes from within. Tech companies have experienced a wave of worker protests over ethically controversial projects (Shane and Wakabayashi, 2018). Even Mark Zuckerberg himself is said to have questioned his "personal techno-optimism" when he realized "that people could abuse the thing that he built" (N. Thompson and Vogelstein, 2018).

This 'techlash' - and the soul-searching it has engendered - have undoubtedly tarnished the (self-)image of tech companies as the world's greatest do-gooders. But they also raise a number of questions. Why did tech companies have this reputation in the first place? Why do tech companies, along with many others, think they are the 'good capitalists' and society's best shot at tackling its biggest problems? Does this (self-)image make a difference in how they are treated by the public, policymakers, and their employees? Do the beliefs that come along with it affect their business decisions or is it merely cover for profit-making? And, not least, how much of this (self-)image has survived the techlash?

In this article, we argue that there is indeed a set of influential beliefs that inform how tech companies see themselves - and how they are seen by others. At the heart of these beliefs is the idea that all good things go together: that one can make money while making the world a better place. This strange "mix of commerce and cause" (Slee, 2016, p. 9) is based on the assumption that the use of digital technologies by inventive and cunning entrepreneurs - is the royal road to fixing social problems. Following Evgeny Morozov Morozov (2013), we call this idea 'solutionist', as it implies that there is a technological solution to every social problem. Much like 
the early protestants believed that economic success is a sign of chosenness, the solutionist entrepreneurs are convinced that if they are doing good, they will also do well; and conversely, that if they are doing well, they must also be doing good. ${ }^{1}$

We argue that solutionist beliefs are a particularly important part of the spirit of digital capitalism, which we define as those normative beliefs that play a legitimizing, motivating and orienting role for today's tech companies. To be sure, when the solutionist beliefs of tech companies collided with their ability to make profits, most of them put profits over principles. The story of tech elites - founders, venture capitalists, senior managers - is thus no exception to the long list of 'cautionary tales' about the difficulties 'enlightened capitalists' face in a world of ruthless and relentless competition (O'Toole, 2019). But this does not mean that solutionist beliefs are inconsequential. Even if capitalists put profit over principles, solutionist beliefs can still justify digital business models both internally (towards employees) and externally (towards policymakers and the public); and they can tip the balance in favor of one course of action when no single profit-maximizing strategy suggests itself.

For the most part, solutionist beliefs are not disingenuous: many tech elites, we argue, really do believe that they are making the world a better place, however misguided this may seem. It seems natural to satirize these beliefs as (self-)deceptions, as HBO's Silicon Valley has done so brilliantly. But as countless interviews, insidestories, and anecdotes illustrate, many in tech really do believe in the liberating potential of technology. Ironically, Google's Astro Teller left a meeting with Silicon Valley's producers in a huff, angrily telling them that "We don't do stupid things here [at GoogleX]. We do things that actually are going to change the world, whether

\footnotetext{
${ }^{1}$ While this solutionist ethic was forged in the cultural crucible of Silicon Valley, we argue that it has assumed a broader significance. Not just because Californian companies play an essential role in the ongoing digital transformation of contemporary societies and economies. But also "because the avatars of [digital] capitalism have persuaded so many people that their way is the way of the future" (Sennett, 2006, p. 12).
} 
you choose to make fun of that or not" (Marantz, 2016). This is not the reaction of an insincere person. Solutionism might be bullshit, but, for the most part, its proponents are not, in Harry G. Frankfurt's sense, bullshitting.

This paper makes several contributions. Conceptually, we reconstruct the concept of the capitalist spirit, and further develop and operationalize it. Theoretically and substantially, we contribute to the budding debate on the moral and ideational embeddedness of economic action (Abend, 2014; Beckert, 2016, 2019; Fourcade and Healy, 2007; Granovetter, 2017) while also elucidating the ideas and values underlying the ongoing digital transformation of economies and societies (Zuboff, 2019). Empirically, we systematically measure the spirit of (digital) capitalism and trace its evolution over time and across sectors. Specifically, we use a supervised classification method (Hopkins and King, 2010; Jerzak, King, and Strezhnev, 2019) on several large and novel text corpora to identify and trace the relative importance of different normative ideas. We also theorize and qualitatively illustrate the significance of these findings for understanding the course and character of digital capitalism.

The paper proceeds as follows. We first give an systematizing overview of the intellectual history of the spirit of capitalism, which we define as those normative beliefs that legitimate, motivate, and orient the actions of capitalist actors (section 2). After describing the solutionist ethic at the heart of the spirit of digital capitalism (section 3), we introduce our data sources and explicate and validate our methodological approach (section 4). We then present our finding and discuss them in light of more qualitative evidence on the legitimizing, motivating, and orienting role of the spirit of digital capitalism. In doing so, we also distinguish our 'newest' from what Boltanski and Chiapello Boltanski and Chiapello (2007) have called the new spirit of capitalism (section 5). We conclude with a brief discussion of the broader theoretical relevance of our argument, not least against the background of the current legitimation crisis of digital capitalism (section 6). 


\section{The Spirit of Capitalism - Revisited}

The concept of the capitalist spirit undoubtedly belongs to the most colorful and controversial concepts in the history of sociological thought. It was first introduced by Werner Sombart in Der moderne Kapitalismus. For Sombart, every economic epoch was defined as much by its predominant economic attitudes - its spirit as by its institutional form (Sombart, 1902). Arguing that the capitalist spirit was defined the combination of acquisitiveness and economic rationalism, Sombart thus laid the conceptual groundwork for an inquiry into the ideational elements underlying capitalist action (Sombart, 1902, p. 391).

Max Weber built on this groundwork when he borrowed Sombart's concept in his famous study The Protestant Ethic and the Spirit of Capitalism. What Weber had in mind, however, was less a cognitive attitude than a "peculiar ethic" (Weber, 2007, p. 17). Weber's capitalist spirit is thus not "mere business astuteness", but an "ethos" the violation of which "is treated not as foolishness but as forgetfulness of duty" (Weber, 2007, p. 17). ${ }^{2}$ Weber's account, however, remains genealogical. The spirit of capitalism fades away after it had performed its midwifely function. Today' capitalism no longer motivates its subjects ethically, but "educates and selects [them] through a process of economic survival of the fittest" (Weber, 2007: 20). Resting on "mechanical foundations" (Weber, 2007, p. 124), capitalism no longer needs the helping hand of its spirit.

Almost a century later, the concept of the capitalist spirit is picked up by Luc Boltanski and Ève Chiapello in The New Spirit of Capitalism. Building on Weber's idea that "people need powerful moral reasons for rallying to capitalism", they define the spirit of capitalism as an "ideology that justifies engagement in capitalism" (Boltanski and Chiapello, 2007, pp. 8-9). While a "minimal argument in terms of

\footnotetext{
${ }^{2}$ Weber consistently uses the concept of the capitalist spirit in quotation marks and limits his use of this "somewhat pretentious phrase" (Weber, 2007, p. 13) to value-rational aspects of economic action (Weber, 2001, p. 50).
} 
compulsory submission to economic laws" might be "a motive for staying in a job" it isn't one "for getting involved in it" (Boltanski and Chiapello, 2007, p. 8). To really mobilize workers - and to defend itself against its tireless critics - capitalism needs "to draw upon resources external to it, beliefs which, at a given moment in time, possess considerable powers of persuasion" (Boltanski and Chiapello, 2007, p. 20).

Drawing on the sociology of justification, Boltanski and Chiapello argue that the spirit of capitalism draws on different orders of worth to do its justificatory work (Boltanski and Thévenot, 2006). The literature identifies eight orders of worth or polities (cités), which we reconstructed and systematized in Table 1. These orders of worth provide actors with criteria for what is valuable or worthy (e.g. efficiency in the industrial polity, recognition by others in the opinion polity); evaluation criteria (e.g. technical performance or productivity, fame or followers); a mode of investment or sacrifice (e.g. disenchantment, the forgoing of privacy); an ideal type (e.g. the manager, the celebrity); a type of insanity (e.g. squander, anonymity); a test (e.g. a formal test procedure, publicity); and an underlying anthropology and cosmology (e.g. the idea that the world can be mastered through calculation and planning, the idea of humans as craving for recognition).

At different stages of capitalist development, the spirit of capitalism appeals to some orders of worth in particular, tapping into the moral resources they provide; the spirit of capitalism is thus always a combination of or compromise between different orders of worth (Boltanski and Chiapello, 2007, pp. 16-19). The first version of the spirit of capitalism - corresponding to the high capitalism of the $19^{\text {th }}$ and early $20^{\text {th }}$ century - is dominated by bourgeois values of thrift, responsibility, and faith in progress, embodied by the market, the domestic and the industrial polity respectively. During the heyday of the managerial capitalism of the $20^{\text {th }}$ century, the industrial polity - with its emphasis on rational organization and bureaucratic planning - massively grows at the expense of the domestic polity, which had glorified 
the company patriarch and not the manager. Finally, with the rise of the knowledge economy in the 1970s, the capitalist spirit increasingly draws on the newly formed project polity and its values of agility, flexibility, and collaboration.

Our own definition of the capitalist spirit is based on this conceptual history. We follow Weber's argument against Sombart and restrict the concept of the capitalist spirit to normative beliefs. And we follow Boltanski and Chiapello's argument against Weber and claim that these beliefs continue to matter but change over time. What Sombart, Weber, and Boltanski and Chiapello hinted at but have not articulated systematically, however, are the legitimizing, motivating, and orienting roles of the capitalist spirit. Spelling them out allows us to systematize the concept of the capitalist spirit and connect it to more recent debates on the moral and ideational embeddedness of capitalist action.

\subsection{Legitimation}

For Sombart, the capitalist spirit was crucial in lending "general acceptance" (Sombart, 1902, p. 379) to acquisitive and rationalistic attitudes that, while essential for capitalism, were long frowned-upon if not stigmatized. Similarly, Weber believed that for capitalism to assert itself in a "world of hostile forces" (Weber, 2007, pp. 2021), it had to tap into the legitimatory power of religious beliefs. Weber also knew that entrepreneurs were rarely received "peacefully"; instead, a "flood of mistrust, sometimes of hatred, above all of moral indignation, regularly opposed itself to the first innovator" (Weber, 2007, p. 31). Weber thus uses the concept of the capitalist spirit in the context of a theory of justifiable actions, in which normative ideas religious or otherwise -subjectively motivate but also intersubjectively legitimate economic actions (Campbell, 2018, p. 12).

Central to Boltanski and Chiapello's account is that idea that capitalism is always subject to criticism. Social critics decry capitalism for producing poverty, inequality, exploitation and egoism; artistic critics denounce capitalism as the source of 
alienation, oppression, disenchantment, and loss of authenticity (Boltanski and Chiapello, 2007, p. 38). Its spirit allows capitalism to selectively appropriate - and thereby diffuse - these criticisms. The new spirit of capitalism, for example, incorporated the artistic critique of managerial capitalism as overly hierarchical and bureaucratic by singing the praise of flat hierarchies, de-centralization, flexibility, and self-reliance. These elements were, of course, highly congenial to the demands of a postindustrial economy. The appropriation of the artistic critique therefore eased the transformation of capitalism to a more flexible but less secure form, while simultaneously stealing its critics' thunder.

More recently, business scholars have emphasized the importance of actively curating one's public image and carefully framing one's economic activities as essential parts of successfully managing one's non-market environment (Bach and Blake, 2016). We argue that the spirit of capitalism amplifies the effectiveness of such legitimacy-seeking strategies by shaping the 'moral background' (Abend, 2014) of the public and political debates on capitalism. The moral background "provides the theories and tools that people and organizations employ to ascertain goodness in the realm of morality" (Abend, 2014, p. 30). By drawing on the theories and tools embodied in the current manifestation of the capitalist spirit, capitalists can 'juice up' the persuasiveness of their legitimacy-seeking activities and thereby ensure favorable regulatory and reputational outcomes (Bach and Blake, 2016; Dror, 2015). 


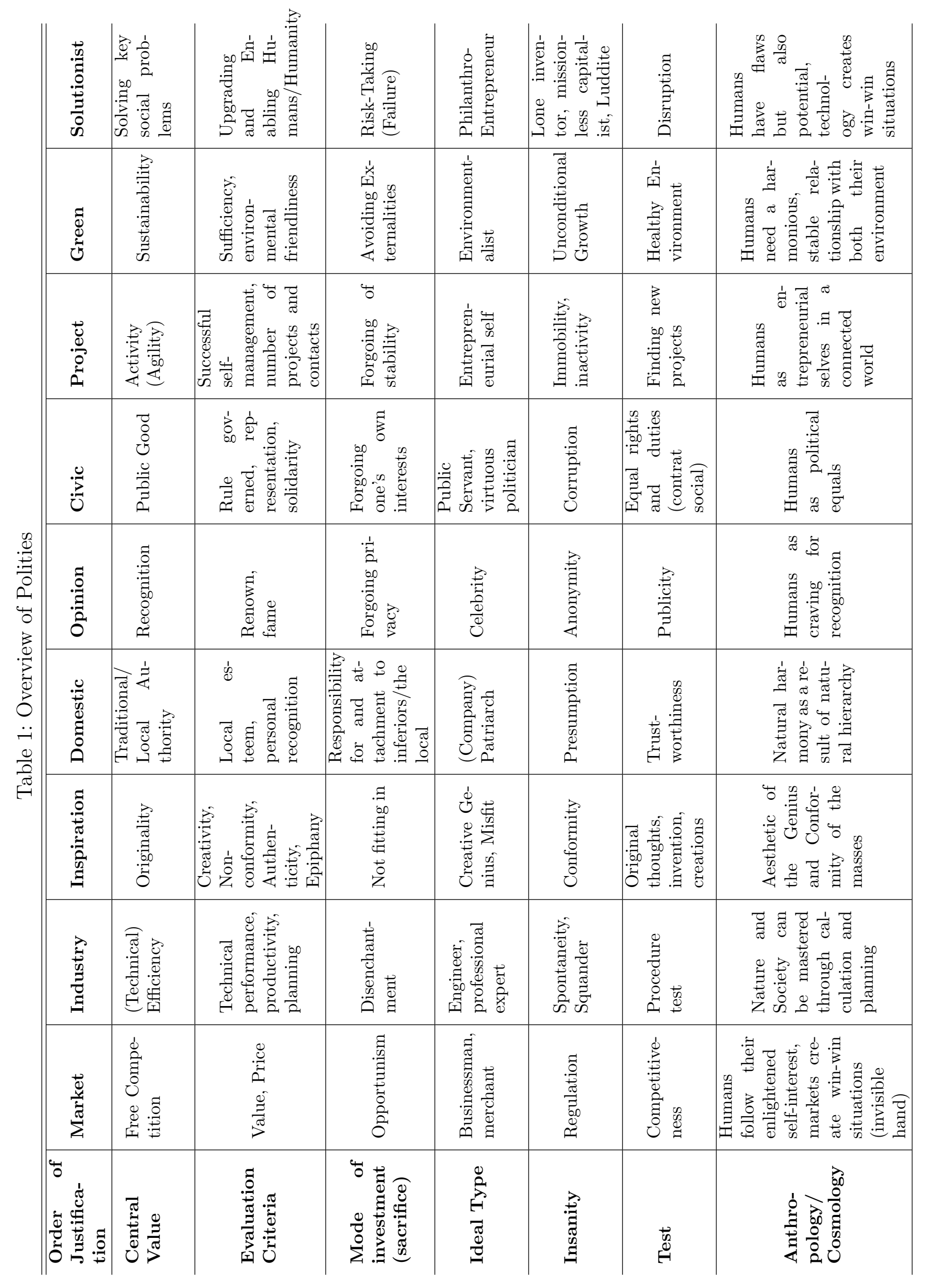




\subsection{Motivation}

Both Sombart and Weber are clear about the central role of the capitalist spirit in creating and sustaining the "dominant motives" (Sombart, 1902, p. XXI) and "psychological sanctions" (Weber, 2007, p. 145) underlying capitalist action. Boltanski and Chiapello also emphasize capitalism's reliance on an enthusiastic workforce, especially for positions of leadership. By incorporating morally appealing ideas, capitalism can "maintain its powers of attraction", i.e. its ability to attract and motivate (elite) workers (Boltanski and Chiapello, 2007, p. 20).

What the theorists of the capitalist spirit have put their fingers on is capitalism's perennial 'motivation problem' (Olma, 2016). How capitalists can motivate workers to not only join their companies, but to give their blood, sweat and tears for them. Companies can, of course, use the stick of organizational sanctions and the carrot of economic rewards. But there are limits to such coercive and economic methods of ensuring compliance (Etzioni, 1975; cf. Habermas, 1988, p. 75). As Bewley Bewley (1999, p. 431) writes:

\footnotetext{
"Workers have so many opportunities to take advantage of employers that it is not wise to depend on coercion and financial incentives alone as motivators. Employers want workers to operate autonomously, show initiative, use their imagination, and take on extra tasks not required by management; workers who are scared or dejected do not do these things."
}

Companies, especially those at the technological frontier, are thus incentivized to employ methods of normative compliance; methods that are meant - and were shown - to instill identification with the company based on shared values and symbolic rewards (Etzioni, 1975; Judge and Kammeyer-Mueller, 2012, p. 349). Since the capitalist spirit periodically incorporates widely held normative ideas (often by coopting them from capitalism's critics), drawing on these ideas can help companies convince their employees that their respective values are aligned and thereby ensure commitment. 


\subsection{Orientation}

Max Weber realized that ideas can be more than mere means of external and internal justification; they can also like "switchmen" (Weber, 1946, p. 280) change the tracks on which (capitalist) actors pursue their economic interests. Recent economic sociology has similarly argued that while capitalists may well want to maximize profits, they rarely know how to go about it, especially when they operate radically innovative sectors. Acting under the shadow of economic uncertainty, they cannot know in advance which investment decision will pay off and which innovations will take off. It is therefore often beliefs - such as heuristics from the past or fictional expectations about the future - that guide the hand of even the most rational and selfish business men (Beckert, 2016; Granovetter, 2017). The moral ideas embodied in the capitalist spirit thus provide capitalists not only with effective justifications in the face of internal and internal criticism, but also with plausible strategies and appealing goals in the face of radical uncertainty (Schröder, 2013).

\section{The Solutionist Ethic}

As its predecessors, the spirit of digital capitalism draws on several orders of worth at the same time. Its defining and distinguishing feature, however, is the strong appeal to the polity of solutionism. Evgeny Morozov defines solutionism as an ideology that recasts "all complex social situations either as neatly defined problems with definite, computable solutions or as transparent and self-evident processes that can be easily optimized - if only the right algorithms are in place" (Morozov, 2013, p. 5). Building on this definition, and on a qualitative analysis of documents by and about digital elites (Nachtwey and Seidl, 2017), we conceive the solutionist polity as an 
order of worth in which value or worthiness derives from solving social problems with technological means and entrepreneurial wit (see also Table 1). ${ }^{3}$

This implies that all relevant social problems can, in principle, be solved technologically; that there is a technological hammer for every social nail. ${ }^{4}$ Social problems are not the result of asymmetries in power or wealth that call for a political solution. Rather, they are the result of inefficiencies and deficiencies that can be eliminated with the right technology (Slee, 2016). This gives solution its characteristic technolibertarian bend (cf. Barbrook and Cameron, 1996). The solution to people's financial difficulties, for example, is not a higher minimum wages or stronger unions, but smart algorithms - offered by companies like Even - that help people manage their budgets more efficiently.

While digital technologies have massively amplified the reach and appeal of solutionist ideas (Morozov, 2013, 15-16), solutionism is not a product of the digital era but has deeper roots: in the culture of engineering and its belief that there is a 'technological fix' to all societal problems (Johnston, 2017) as well as in the "New Communalist ethos of tool use" (Turner, 2006, p. 238) and their faith "that experimentation and the proper deployment of the right technologies could save the world" (Turner, 2006, p. 244). These techno-optimist tendencies are amplified by the culture of coding, which nurtures an "almost aesthetic (...) dislike for inefficiency" (C. Thompson, 2019, p. 21); and a hubristic control illusion that understands social problems in the same way as coding problems by extrapolating from the programmer's intuition that one "can program any procedure [one] thoroughly understand $[\mathrm{s}] "$ (Weizenbaum, 1976, pp. 103-104). Such "computational thinking"

\footnotetext{
${ }^{3}$ Others have used different concepts to describe similar ideas. For example, Meredith Broussard Broussard (2018, p. 14) coins the term "technochauvinism" to describe the "belief that tech is always the solution"; and James Bridle Bridle (2018, p. 4) uses the term "computational thinking" to describe the belief "that any given problem can be solved by the application of computation". ${ }^{4}$ Bill Gates uses the same metaphor: "Any problem I will look at how technical innovation can help solve that problem. It's the one thing I know and the one thing I'm good at. That's my hammer. And a lot of problems look like nails, because I've got a hammer" (Schlosser, 2019).
} 
(Bridle, 2018, p. 4) is perfectly epitomized by Mark Zuckerberg's 'first principle' of engineering, which says that one should 'think of every problem as a system and every system can be better. No matter how good or bad it is, you can make every system better'.

But despite the importance of technology, the solutionist is more than just an engineer or coder. She is, in Schumpeter's sense, not an inventor but an innovator - someone who commercializes an invention. An invention that cannot be commercialized is a lost invention. Larry Page realized this when he was still a boy. Reading a biography of Nicola Tesla, who was a brilliant inventor but a terrible business man, he concluded:

"You don't want to be Tesla. He was one of the greatest inventors, but it's a sad, sad story. He couldn't commercialize anything, he could barely fund his own research. You'd want to be more like Edison. If you invent something, that doesn't necessarily help anybody. You've got to actually get it into the world; you've got to produce, make money doing it so you can fund it" (Serwer, 2008).

Therefore, to really make a difference, the solutionist needs to be an entrepreneur as much as a technologist. But the solutionist is not just an entrepreneur; she is a philanthro-entrepreneur. In the solutionist worldview, making money and making the world a better place are not mutually exclusive but can and should go hand in hand. Silicon Valley, as Tom Slee put it, "may have its share of the world's richest people, but it has always seen itself and presented itself as being about more than money: it's also about building a better future" (Slee, 2016, p. 9). The solutionist not only abhors the lone inventor, who has her way with technology but has no business model. She also rejects those who lack a purpose and are only in for the money (like those on Wall Street).

Purpose alone, however, without technology and a viable business model, is equally flawed. Hence the rejection of traditional politics as the best way to address social ills - a rejection that echoes the New Communalists turn "toward social and economic spheres as sites [of] social change (Turner, 2006, p. 244). Solutionism 
shares this sentiment with philanthrocapitalism - the idea and practice of applying a business logic to philanthropy in order to make it more efficient, impacted-oriented and financially profitable (McGoey, 2012). Many tech elites in fact use their technological and business acumen to make charity bigger, bolder and more data-driven (Stanley, 2015). But while both solutionists and philanthrocapitalists portray public and private interests as mutually compatible, they do so from opposite directions, as it were.

Philanthrocapitalism is about the "idea that charity is good business" and can therefore be profitable (McGoey, 2012, p. 187). Solutionism, on the other hand, is about the idea that business itself can be philanthropic. In the solutionist worldview, there is a natural alignment between business opportunities and social problems. "Want to become a billionaire? Then help a billion people. The world's biggest problems are the world's biggest business opportunities" (Diamandis, 2020). Philanthropy is thus neither a separate stage of life nor a more or less profitable side business. Whereas traditional philanthropist in the wake of Carnegie had espoused the idea that "after-the-fact benevolence justifies anything-goes capitalism; that callousness and injustice in the cutthroat [marketplace] are excused by later philanthropy" (Giridharadas, 2018, p. 164), the solutionist has a different take. Doing good is not an atonement for doing well, but simply the other side of the same coin. "It's been a yin and yang equation", as Tom Werner puts it: "We're changing the world on one side and building a great company on the other side" (Hull, 2014).

While capitalists have always justified their profit-seeking activities with reference to some abstract notion of the common good - usually some version of Smith's invisible hand -, solutionists believe that businesses can contribute to the common good much more directly. In this "new, postmodernized version of Adam Smith's invisible hand" (Žižek, 2006), companies with the grandest purpose will miraculously also be the companies with the biggest profit. Underlying this idea - that all good things go together - is an "almost religious faith" (Giridharadas, 2018, p. 41) in 
the harmony of human interests and the ability of technologies to create win-win situations.

"What's amazing about tech $(\ldots)$ is that there are so many opportunities to have your cake and eat it, too $(\ldots)$ There's a stereotype that you have to choose in life between doing good and making money. I think for a lot of people that's a real choice (...) But for technology, there are a significant number of opportunities - Google search being the most massive example of all time - where we simultaneously are doing something lucrative and really good for the world. [A] lot of times you can get in situations where they're all aligned, where the bigger the reach of the good you're doing, the more money you'll make" (Justin Rosenstein in Giridharadas, 2018, p. 41).

This notion, that in an age of brilliant technologies, "entrepreneurship can become synonymous with humanitarianism" (Giridharadas, 2018, p. 47), is based on a worldview that understands individuals and societies as simultaneously flawed and full of potential. There is a tension between what is possible - given the laws of physics - and what is realized. Erasing this tension is the source of the solutionist impetus. This idea finds its expression in the techno-utopist "rhetoric of potentiality" (Dickel and Schrape, 2017, p. 47). The world is full of bugs but can be fixed with the right technology. It is the calling of every solutionist to do just that: upgrade humanity by becoming a social engineer in the true sense of the word. For now, the focus is on giving humans access to information and to connect them with each other; for through "the power of technology, age-old obstacles to human interaction, like geography, language and limited information, are falling and a new wave of human creativity and potential is rising" (Schmidt and Cohen, 2013, p. 4). But the end-game is much grander: solving humanity's oldest problems - old age, sickness, death - by upgrading humans themselves.

Animated by the normative power of the possible, solutionists have little respect for the status quo - and the institutions that maintain it. Hence the veneration for pioneers and disruptors. If the status quo is flawed but also full of potential, the pioneers and disruptors are but the harbingers of a better future. Breaking the law 
becomes civil disobedience in the name of a better world. "You can't change the world without a certain amount of healthy willingness to break the rules" (Sebastian Thrun in CBS News, 2014). And if change is a good thing, more change is even better. "If you change the lives of one hundred million people, you are not successful. You are only successful if you change the lives of 1 billion people" (Sebastian Thrun in Schulz, 2014). This, of course, requires audacity and the willingness to fail, since "failure and invention are inseparable twins" (Bezos, 2015). But for those hungry and foolish enough, the rewards will be big - not in the hereafter, as for the protestants, but in the here and now. Daring to dare becomes something of an ethical commandment.

\section{Data \& Methodological Approach}

To test our arguments, we collected three novel text corpora and devised a coding scheme for hand-coding documents into the different polities. We then used these hand-labeled documents to estimate the proportion of documents in each category in the larger corpora.

\subsection{Data}

Each corpus serves a distinct analytical purpose. The first corpus consist of public statements of digital elites in which they talk about themselves or their worldview (e.g. interviews, speeches). Digital elites are here narrowly defined as members of the 2015 Forbes 400 who played crucial roles (e.g. founder, CEO, major investor) in tech companies founded after 1996, and therefore made most of their money in the last 20 years or so (it thus excludes 'first-generation' digital elites like Bill Gates and Steve Jobs). The purpose of this sampling procedure - which resulted in 2326 paragraphs - was to identify the spirit of digital capitalism where we would most expect it: in the professed beliefs of the most recent generation of digital elites - 
individuals like Larry Page, Mark Zuckerberg or Elon Musk. ${ }^{5}$ The second corpus consists of articles published in Wired between the magazine's founding in 1993 and 2019, which we scraped from the web and split into paragraphs. After removing very short paragraphs, we ended up with a total of 1.514 .839 paragraphs. Wired is widely known as the house organ of the tech community, and thus a greats source for understanding the intellectual proclivities, fads, and currents of the wider tech milieu. ${ }^{6}$ The third corpus consists of articles published in the Harvard Business Review (HBR) between 1985 and 2020, which we also scraped from the web and split into paragraphs. Again, after removing very short paragraphs, this resulted in a total of 161.204 paragraphs. The purpose of this corpus is see to which extent the spirit of digital capitalism has already diffused into the mainstream of management literature and capitalist self-reflection, which HBR arguably represents more than any other outlet. ${ }^{7}$

\subsection{Methodological Approach}

Our coding scheme is the result of a iterative process of theory-building and empirical validation, where theoretically derived - or, in the case of the solutionist polity: qualitatively developed - polities were specified and disambiguated in multiple rounds of coding. ${ }^{8}$ This iterative procedure was meant to balance theoretical ambition and empirical reliability and feasibility. Our unit of analysis were paragraphs, as they are often natural units of meaning; they often make, as it were, a point, and are short enough to be relatively unambiguous and long enough to be informative. Paragraphs were assigned to a polity when they contained a clear and affirmative reference to one of the normative principles laid out in Table 1. If paragraphs were purely descriptive or did not unambiguously refer to one polity, they

\footnotetext{
${ }^{5}$ While some digital elites publicly express themselves more frequently than others, we have at least one and no more than 8 documents for each of the 30 digital elites identified on the Forbes 400. For more details on the sampling procedure, see subsection A.1

${ }^{6}$ For details, see subsection A.2

${ }^{7}$ For details, see subsection A.3

${ }^{8}$ The coding scheme can be downloaded from https://timoseidl.com/publications/. Replication Materials will be made available at a later point.
} 
were assigned to a residual category. Here are two examples of paragraphs that were coded as solution and market respectively:

"We are investing in driverless technology (...), why? Well a million people a year die in cars, and how many more millions get injured, it's just needless right, and how much time, how much worse is our lives because we're sitting there with a steering wheel in our hands being stressed out and frustrated with traffic remember, (...) when you can give people their time back, and when you run these cars more efficiently and there's no more traffic, this is magic."

"No. We are thinking in terms of purely commercial, business relations. Neither 'friendship' nor 'international cooperation' can be an excuse for not making a profit. These new ventures are very important strategically for us."

Since our dataset contains several hundred thousand paragraphs, we used a supervised learning approach to estimate category proportions for the corpora based on a set of hand-coded paragraphs. This involves three steps (Grimmer and Stewart, 2013, p. 275). First, we hand-coded 1518 documents from all three datasets. After extensive coder training (done, of course, with different documents), we achieved good reliability scores on various metrics (Krippendorff's alpha $=0.7) .{ }^{9}$ Most disagreements between coders were the result of one coder opting for the residual category. This suggests that the polities themselves are quite distinct but that coders sometimes have difficulties assessing whether or not a statement is unambiguous or clear enough to qualify for a certain polity. If we remove documents with such disagreements, the reliability scores become very good (Krippendorff's alpha $=0.87$ ).

Second, based on the labelled training set we infer category proportions in the unlabeled test set using an method of automated nonparametric content analysis called readme (Hopkins and King, 2010; Jerzak, King, and Strezhnev, 2019). Most supervised learning techniques are optimized to classify individual documents and follow a parametric 'classify and count' logic; readme, by contrast, 'directly' estimates the proportion of documents in each category, which has been shown to

\footnotetext{
${ }^{9}$ For more details, see B
} 
produce less model dependent and biased results (classifiers can produce biased estimates of proportions even if they correctly classify a high number of documents) (Hopkins and King, 2010: 234). readme makes the crucial assumption "that the labelled conditional feature matrix is an unbiased estimator of the unlabeled conditional feature matrix" (Jerzak, King, and Strezhnev, 2019, p. 6), that is, that the hand-labelled documents contain word profiles - or examples of language use sufficiently similar to those in the test set (Hopkins and King, 2010, p. 237). Given that the hand-labelled documents are a random subset of the unlabeled documents and thus cover the same time (relatively short) period, we are confident to meet this assumption.

The third step is to validate the model output, and based on the results, to estimate the category proportions for (time-slices of) the various corpora. Since we are not classifying individual documents, traditional validation metrics like accuracy or recall are not available. To validate our results, we thus produced 100 random $50 / 50$ splits of the 1203 correctly coded paragraphs and run readme on each of these training set/test set splits. Since we know the 'true' proportion of each category in the test sets, we can compare them to the category proportions estimated by readme. For our analysis, we use the $\mathrm{R}$ package readme2, which improves on the original readme package in two ways: first, it uses pre-trained dictionaries of word vectors to improve the choice of optimal features from a large space of potential document summaries in a way that maximizes textual discrimination between categories; and is uses matching techniques to remove documents from the labelled set that are so different from those in the unlabeled set that they are unlikely to result from the same data-generating process (which may happen due to semantic change) (Jerzak, King, and Strezhnev, 2019).

Figure 1 shows that readme2 produces roughly accurate predictions for the various categories. While the residual category is considerably underestimated, especially if we remove unmatched word stems, this seems acceptable since readme 'spreads' the 
unused percentages relatively evenly across the other categories. This also makes sense given that the residual category contains paragraphs that make references to multiple polities. Thus, while we may not be able to interpret small differences due to these errors, we can give good estimates of the prevalence of different types of normative justification and we can trace larger shifts in their relative importance. ${ }^{10}$
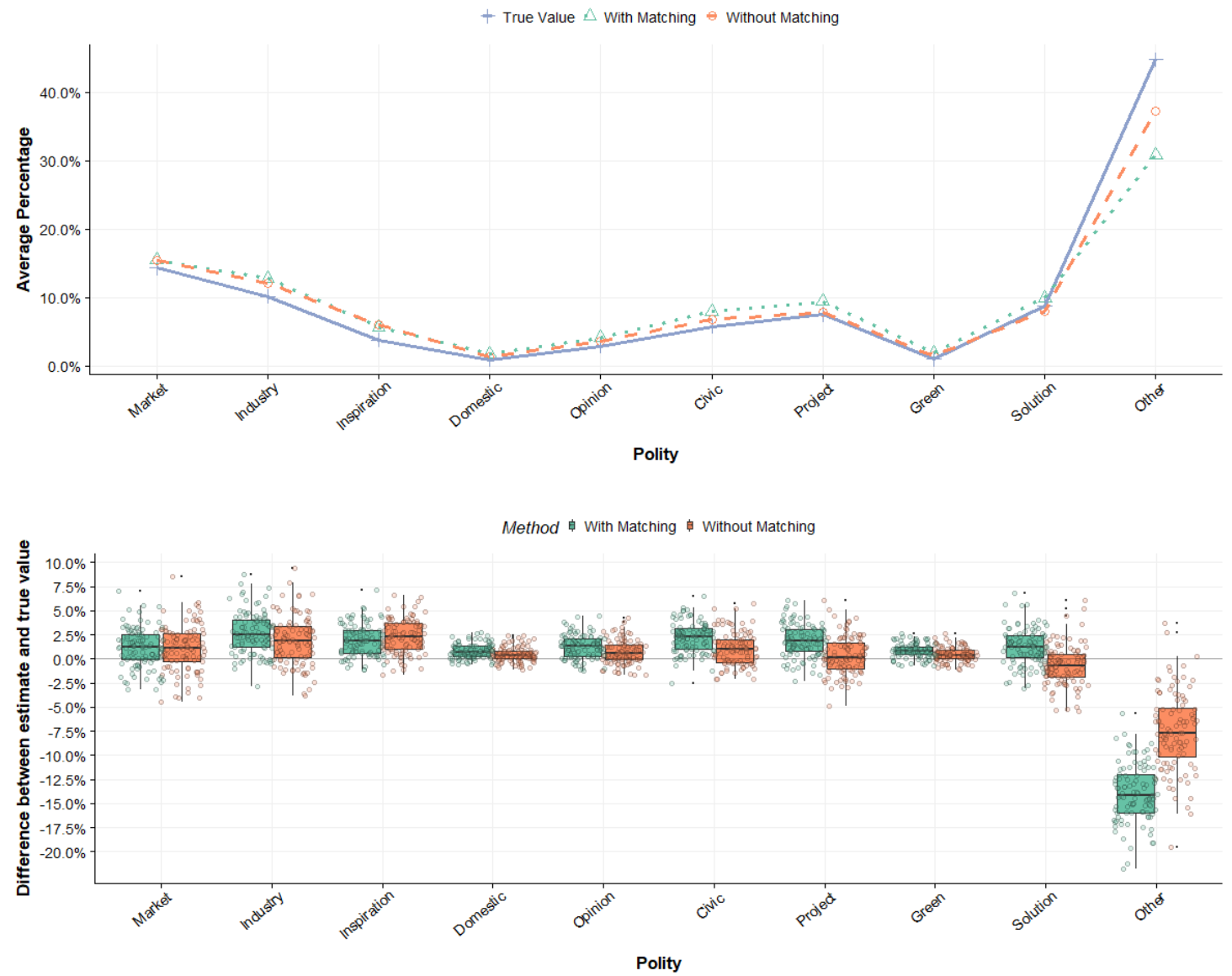

Figure 1: Estimated and true category proportions (individual dots refer to the results of different runs)

\footnotetext{
${ }^{10}$ In the paper, we present the results of readme 2 with matching. However, as $\mathrm{C}$ shows, the results are quite similar if we do not use matching, and our substantive interpretations remain the same.
} 


\section{Results \& Discussion}

Which are the values digital elites refer to in their speeches and interviews? In other words, what is the normative (self-)image they have or want to project? We find a belief in the world-improving power of technological entrepreneurship is indeed central to the belief system of digital elites, closely followed by the faith in the blessings of the market and the value of efficiency (Figure 2). Meanwhile, the traditional authority of the domestic polity, the vain desires of the opinion polity, and ecological values of sustainability are - perhaps surprisingly - less important. While this confirms our argument that digital elites are indeed enthralled by solutionist ideas, one might argue that for all their lofty rhetoric, digital capitalist are still capitalists: so why should we care about their solutionist sermons? Are they not just cheap talk, rhetorical veneers on the stony reality of capitalist profit-seeking? We think that one should care, for three reasons.

First, solutionist ideas have come to define not just how tech elites see themselves but also how they are seen by others and thereby legitimized them in the eyes of policymakers and the public. In that sense, even if they are veneers, they helped stabilize what they were meant to cover. Second, their solutionist credentials helped tech companies convince their workers that their values and those of the company are aligned. If tech workers believe that the authority of tech elites is legitimate because both want to use technologies to make the world a better place - compliance costs will decline and motivation increase. ${ }^{11}$ Conversely, if these companies violate solutionist principles, worker engagement will turn into resistance. In that sense, talk is not always cheap. Third, even if what tech elites publicly profess is not what they privately feel, solutionist ideas might still guide their profit-seeking activities

\footnotetext{
${ }^{11}$ Weber himself believed that legitimate rulers, i.e. rulers that can justify their rule on rational, traditional, or charistmatic grounds, can exercise their authority more effectively that if they had to rely on brute coercion. There is every reason to believe that this is also true for capitalist organizations.
} 


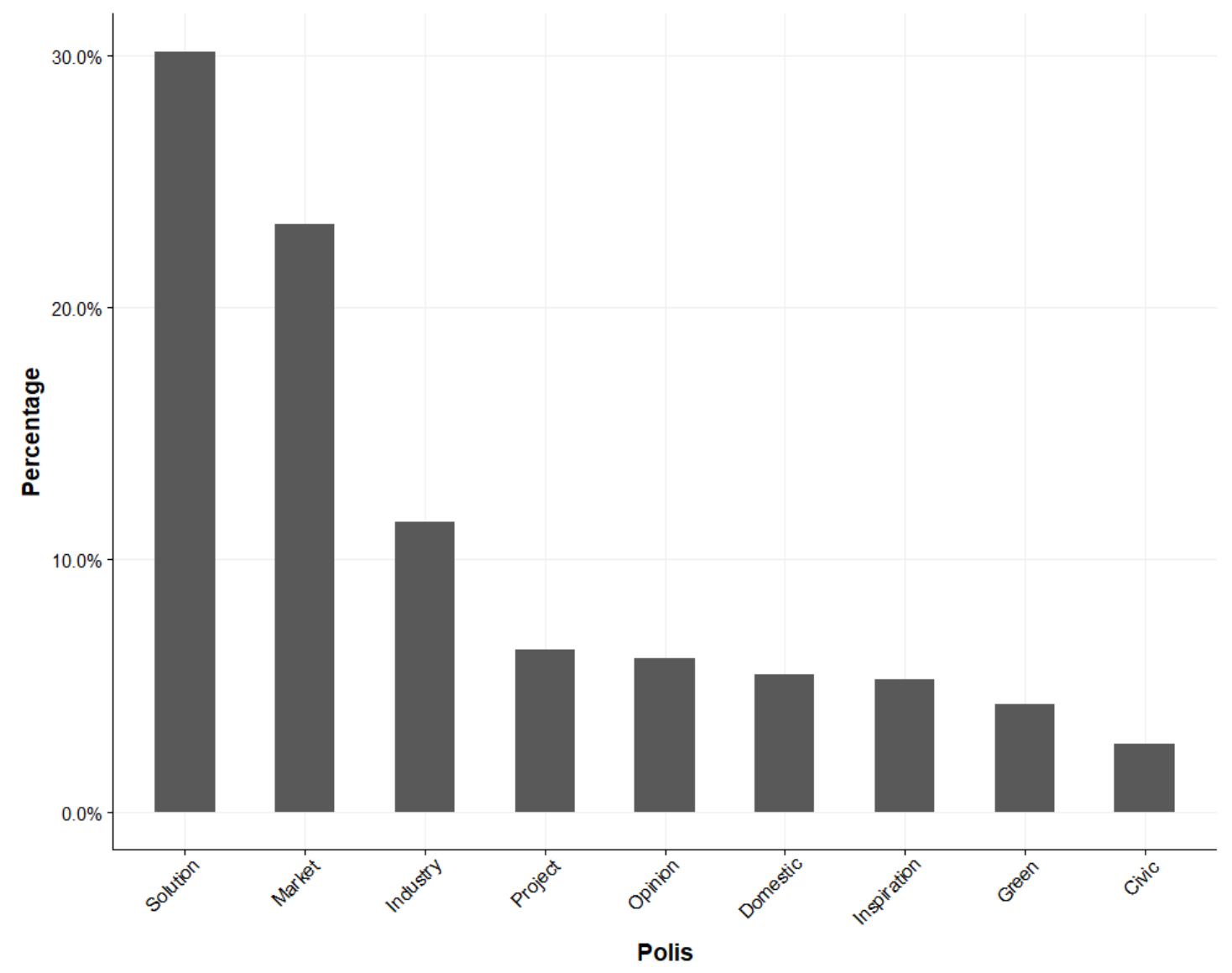

Figure 2: References to different polities in statements by digital elites

by pointing them towards problems that promise large profits. In that sense, even the loftiest rhetoric may be consequential. Let us discuss these points in turn.

\subsection{Legitimation}

Perhaps the most surprising thing about the recent techlash is how late it came. Given their central role in contemporary economies and societies, how could tech companies get away with so little regulatory oversight and political scrutiny for so long (Zuboff, 2019, p. 100)? Our answer is that they were not only very adept in managing their non-market environment, but could also exploit a favorable moral background in which solutionist ideas had already taken hold (Abend, 2014). At a time when capitalism was increasingly criticized for producing private but not 
public wealth and for creating rather than solving social problems, solutionism lend legitimacy to those that promised to harness the power of entrepreneurship and technology for the common good - and thereby also to capitalism itself. It was easy, for a company like Uber, for example, to win over regulators by promising to solve 'grand societal challenges' such as safety, harassment, or transportation (Uzunca, Rigtering, and Ozcan, 2018).

In addition, solutionism provided a powerful rationale for limiting regulatory oversight and political scrutiny. Who, after all, is the government to stop tech companies from tackling many of the problems the government itself is no longer able to solve? Even Bill de Blasio, certainly no friend of big-tech, acknowledged that Silicon Valley's "technology-religion pushed away the notions that [tech companies] should be regulated, very effectively" (Blasio, 16.09.2019, 41:29-41:34). This legitimizing function of the capitalist spirit is essential in understanding the nature of digital capitalism. For a central belief of many tech elites - and often a crucial part of their business model - is the assumption that "lawlessness is the necessary context for "technological innovation"' (Zuboff, 2019, p. 104). Larry Page, for example, has argued that "[o]ld institutions like the law and so aren't keeping up with the rate of change that we've caused through technology" and only hamper Google's ability to "build really great things" (Zuboff, 2019, p. 105). And it was as late as 2013 that Eric Schmidt and Jared Cohen Schmidt and Cohen (2013, p. 3) wrote that the digital world, "the world's largest ungoverned space", was "not truly bound by terrestrial laws". That such claims have, until recently, largely been accepted is not only the result of skillful lobbying and a congenial neoliberal zeitgeist. It is also the result of a favorable moral background that allowed tech companies to convince others that they were indeed making the world a better place, and that regulation would only limit their ability to do so (Zuboff, 2019, pp. 101-127). 


\subsection{Motivation}

While many have mocked Google's famous former motto 'Don't be evil', fewer have appreciated its significance (Foroohar, 2019). For it not only provided means to align the company's values with those of its workers and thus ensure the latter's engagement and loyalty, it also significantly limited Google's operational leeway. 'Don't be evil' is more than a branding ploy. Many Googlers really believe - or at least believed - in the company's mission, which is evident from our own interviews with them in both California and Europe as well as from the accounts of others (Foroohar, 2019). And these beliefs put limitations on what Google can and cannot do. A recent inside-story, for example, recounts that to "a remarkable extent, Google's workers really do take 'Don't Be Evil' to heart. C-suite meetings have been known to grind to a halt if someone asks, 'Wait, is this evil?'” (Tiku, 2019).

Ignoring these limitations, which Google has repeatedly done, comes at the cost of worker disengagement and even resistance - the price Google has to pay for the motivational power of its solutionist rhetoric. This is exactly what happened during the recent wave of tech worker resistance. For example, a contract between Google and the Pentagon about the use of Artificial Intelligence to improve the targeting of drone strikes has proven deeply controversial among employees and has "touched off an existential crisis" at the company (Shane and Wakabayashi, 2018). Incidents like this lay bare some of the political differences between the more libertarian tech elites and the more liberal tech workers - differences that the solutionist rhetoric had long masked (Weigel and Tarnoff, 2019). As one Googler put it:

"Libertarianism is the ethos of the leaders of these big tech companies, not the rank and file. Our campaign had nothing to do with libertarianism. We stood up because (...) we believe a strong ethical framework that values human life and safety is inseparable from positive technological progress (...) Before the [protests against Project Maven], a lot of Googlers had never considered the fact that their values might not be aligned with the values of leadership. (...) Ultimately, the Project Maven campaign wasn't just about whether Google should build this one tool for the 
military. It was about using our power as workers to ensure that technology is built for social benefit and not just for profit." (cited in Tarnoff, 2018).

One of the reasons for the success of tech workers - Project Maven was eventually cancelled - was that tech workers could hold the tech companies "hostage to [their] own public image" (Tiku, 2019). And this public image matters if companies want to recruit the best and brightest workers. Tech workers care about the "mission of the company and what the companies are trying to achieve"; "employees", as one recruiter put it, "are wising up to the fact that you can have a mission statement on your website, but when you're looking at how the company creates new products or makes decisions, the correlation between the two is not so tightly aligned" (Bowles, 2018). Across elite universities, there is "a growing sentiment that Silicon Valley's most lucrative positions aren't worth the ethical quandaries" (Goldberg, 2020). Facebook, in particular, had an increasingly difficult time recruiting talent "as the social stigma of working for Facebook began outweighing the financial benefits" (Bowles, 2018). In short, the spirit of digital capitalism can supply powerful non-economic incentives, but it comes at the price of normative and economically costly commitments that capitalists can only ignore at their peril.

\subsection{Orientation}

When Mark Zuckerberg was urged to sell Facebook to Yahoo! in 2006, he refused, arguing that he holds the "really deep belief that when companies are executing well on their vision they can have a much bigger effect on the world than people think, not just as a business but as a steward of humanity" (Friend, 2015). Here, the idea that Facebook could be a 'steward of humanity' helped Zuckerberg make a decision laden with much uncertainty; Zuckerberg would have arguably decided differently were he only in for the money.

Solutionist ideas, however, not only affect what entrepreneurs do with their companies, but also how they allocate resources within them - or how venture capitalists 
and financial actors allocate resources to them. Venture capitalist John Doerr, for example, puts his money in missionaries, not mercenaries because he beliefs that the best entrepreneurs are those that not only care about success but also about significance (Taylor, 2016). And Google spends billions tackling huge problems with radical but feasible solutions not just because this "sends a corporate signal, both internally and externally, that [it] still nurtures the idealism" on which it was founded" (D. Thompson, 2017); but also because it beliefs that solving humanity's great problems is the surest way to make Google even richer. Google's technological imaginaries, in other words, create an imagined future that focuses the company's present activities while instilling investors and the public with fictional expectations that boost the companies economic reputation and market value (Beckert, 2016). These orientational processes can undoubtedly be very self-serving, as Fred Turner recounts:

"About ten years back, I spent a lot of time inside Google. What I saw there was an interesting loop. It started with, 'Don't be evil.' So then the question became, 'Okay, what's good?' Well, information is good. Information empowers people. So providing information is good. Okay, great. Who provides information? Oh, right: Google provides information. So you end up in this loop where what's good for people is what's good for Google, and vice versa" (Turner, 2017).

What is easily missed here is that the belief that information is good nudged Google to focus on those products - of all possible products - that would put Google in a position to 'organize the worlds information'. This is was what being good meant, after all, so Google focused its investments in 'information-organizing' products such as maps, books, or news, which eventually proved highly profitable. By providing actors with beliefs about what is right and wrong, the spirit of capitalism can thus mitigate economic uncertainty by pushing capitalists towards certain 
potentially profitable directions and away from others, guiding their hand when economic rationality does not dictate any single course of action. ${ }^{12}$

\subsection{Solutionism in the Wider Tech Milieu}

However, even if we accept that solutionists ideas have taken hold in the hearts and minds of digital elites, we still don't know whether they have spread beyond this exclusive circle. How, one might ask, do they fare in the wider digital milieu. Figure 3 depicts the evolving importance of different orders of worth in Wired, widely considered "the mouthpiece of the digital revolution" (Wolf, 2003: 52). While solutionist ideas are somewhat less important in the wider tech milieu than for the digital elites themselves, they do play a considerable role, especially after the dot.com bust and the financial crises. More recently, as the techlash gathered steam, the ascent of solutionist ideas has slowed down a bit; however, as we discuss in the conclusion, it would be premature to write solutionism off. Interestingly, the civic polity plays an important role during the era of early internet regulation in the 1990s, becomes less important in the 2000s, just when the solutionist polity gains ground, and rises again more recently as tech became increasingly politicized.

The projective polity, meanwhile, remains fairly marginal. This is somewhat surprising, given that the discourse on digitalization is often associated with the 'Post-Fordist' values of decentralization and authenticity. Eran Fisher, for example, has argued that whereas Fordist technology discourse extolled the ability of technology to mitigate the exploitative aspects of capitalism (instability, insecurity, inequality), Post-Fordist technology discourse promised to overcome "the alienating components of capitalism" while downplaying "its exploitative components" (Fisher,

\footnotetext{
${ }^{12}$ This orientational function can also help capitalist coordinate their behavior. Much like fictional expectations, they can "help economic actors work in concert in the face of uncertainty: if they share a conviction that the future will develop in a specific way and that other actors will thus behave in foreseeable ways, they may use these expectations to coordinate their decisions. [They thus] contribute to the dynamics of capitalism, since the correspondence of expectations, or 'frame alignment', anchors decisions for investment and innovation" (Beckert, 2016, p. 11).
} 


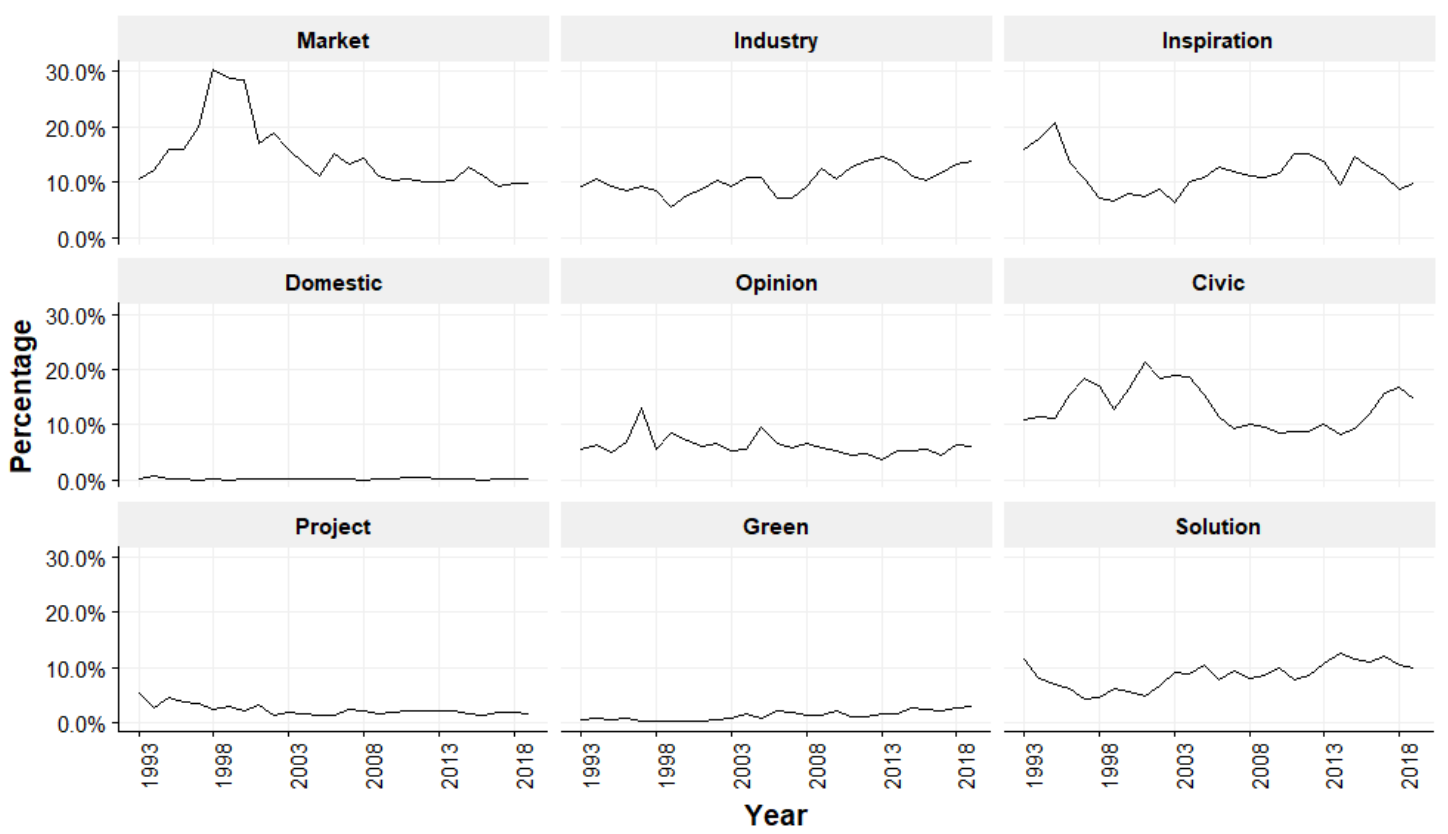

Figure 3: References to different polities in Wired paragraphs (1993-2019)

2010, p. 235). According to Fisher, the new, post-Fordist spirit of capitalism is "inextricably linked with network technology discourse" (Fisher, 2010, p. 243) and its promise of flat hierarchies and a more authentic but also more flexible capitalism. ${ }^{13}$ Thus, while Fisher highlights the role of new (network) technologies in amplifying the appeal and reach of Boltanski and Chiapello's new spirit of capitalism, he also conceptualizes this spirit as a "spirit of networks" (Fisher, 2010, p. 243) - just like Boltanski and Chiapello have argued that capitalism's new spirit makes "the network a normative model" (Boltanski and Chiapello, 2007, p. xxii); and just like Manuel Castells has argued that a "spirit of informationalism" will serve as the "ethical foundation of the network enterprise" (Castells, 2010, p. 214). And indeed, in the eyes of a highly influential group of cultural entrepreneurs around Steward Brand and Kevin Kelly, digital technologies - and the internet in particular - were

\footnotetext{
${ }^{13}$ Similarly, Gary Yeritsian has argued that the new spirit of capitalism - with its emphasis on engagement, sharing, and horizontality - has diffused from the office space of the cadres into the social factory of the Web 2.0, promising digital laborers in symbolic rewards what they lack in material compensation (Yeritsian, 2018).
} 
the symbol of a new social and economic order (Turner, 2006, p. 202). Drawing on a long history of cybernetic and countercultural ideas, this group argued that the digital entrepreneurs of the late $20^{\text {th }}$ century

"would do what the New Communalists had failed to accomplish: they would tear down hierarchies, undermine the sorts of corporations and governments that had spawned them, and, in the hierarchies' place, create a peer-to-peer, collaborative society, interlinked by invisible currents of energy and information" (Turner, 2006, p. 209).

By joining "the cultural legitimacy of the counterculture to the technological and economic legitimacy of the computer industry" (Turner, 2006, p. 219), these cybercultural apostles not only legitimized a hands-off approach to internet regulation. They also articulated a broader vision of a society - often called the Californian ideology (Barbrook and Cameron, 1996) - in which digital technologies would "marry the competitive demands of business with the desire for personal satisfaction and democratic participation", achieving "productive coordination without top-down control" (Taylor, 1994). The internet promised an escape from the iron cage of Fordism; it "became both a metaphor for [a post-Fordist society] and a means to bring it into being" (Turner, 2006, p. 219).

Our results partly corroborate these findings. We do not find many references to the projective polity in the Wired corpus (though, as we will see shortly, we do find them in the HBR corpus). But we do see the valuation of non-conformity, authenticity and anti-regulationism reflected in the prominent role of the inspiration and market polity - particularly in the 1990s. This is also in line with Wired's libertarian and somewhat esoteric bend, especially during its early days. Thus, a central implication of our argument and our empirical findings is that despite the close connection between the internet and Post-Fordist values, the spirit of digital capitalism is distinct from the network-centered, post-Fordist spirit of capitalism. To be sure, the projective polity has not been abandoned, as is evident from both Figure 2 and Figure 3. Just like its predecessors, the spirit of digital capitalism is a 
compromise between different polities. But its defining feature is not the appeal to values of the projective polity, but to those of the solutionist polity.

Crucially, it was the changing nature of capitalism itself that undermined the justificatory power of the projective polity and ushered in solutionism. The projective polity was congenial to a type of capitalism that put networks over hierarchies, project-based collaboration over formalized division of labor, and flexibility over security. Historically, it offered a plausible defense against the artistic critics of Fordist capitalism, and an appealing justification for its neoliberal, post-Fordist successor. Its hero, the entrepreneurial self, navigates a networked world of changing projects while constantly trying to learn and innovate (Bröckling, 2016). The solutionist polity, by contrast, is less a reaction to the artistic critique of the alienating aspects of capitalism than to the social critique of capitalism's lack of solidarity and concern for the common good. It is congenial to a type of capitalism - epitomized by Wall Street - that is rampant with individualism and seemingly devoid of a social contract. The solutionist hero, the philanthro-entrepreneur, uses his business acumen and tech-savviness to optimize the world - not just himself, and it is not surprising that solutionist ideas gained prominence after the globalization protests of early 2000s and the financial crisis. ${ }^{14}$

At a time when the promissory legitimacy of neoliberalism - its ability to plausibly promise a better future - has exhausted itself (Beckert, 2019), solutionism took up (part of) the slack. The spirit of digital capitalism no longer justifies an economic order that is primarily plagued by rigid Fordist hierarchies, but one that is beset by post-Fordist selfishness, precarity, and lack of civic-mindedness. Digital technologies are once again heralded as a panacea for capitalism's ills. But this time

\footnotetext{
${ }^{14}$ As we can in Figure 3, solutionist ideas seem to have gained in prominence after the bursting of the dot.com bubble, which drove out the more mercenary "carpetbaggers" and left behind the more idealistic "true believers" (Tacy, 2011). Moreover, the 'PayPal Mafia' around Peter Thiel and Elon Musk, many of them ardent solutionists, played an outsized role in funding and shaping many startups in the early 2000s, as venture capital retrenched and they filled the void (Mcnamee, 2019, p. 48).
} 
they do not promise to "flatten organizations, globalize society, decentralize control, and help harmonize people" (Nicholas Negroponte in Turner, 2006, p. 1). Rather, they claim to solve society's problems root and branch, from traffic deaths to death itself. These differences are related to differences in the underlying technologies. While miniaturization and networking were the central technological developments during the heyday of the projective polity, today's technological landscape is dominated by Artificial Intelligence and platform infrastructures. Due to the centripetal, centralizing tendencies, the later lend themselves to solutionist applications more than personal computers or the internet.

\subsection{Solutionism and Capitalist Self-Reflection}

The anti-statist and technophile tendencies of the Californian counterculture have thus found a new home in the solutionist worldview. And while they find their most fierce adherents in the elites of today's platform capitalism, they also made their way into the wider digital milieu. ${ }^{15}$ But did solutionist ideas also make headways outside of tech elites and the wider tech community? Figure 4 depicts references to the different orders of worth in the HBR - perhaps the central venue for capitalist self-reflection. Unsurprisingly, we find that the values of the industrial and market polity play a prominent role in a magazine that is centrally concerned with the efficiency of organizations and the functioning of markets. What is remarkable, however, is that the project polity becomes a lot more important in the 1990s while

\footnotetext{
${ }^{15}$ Weber made clear that the spread of attitudes associated with the spirit of capitalism required "long and arduous process of education" (Weber, 2007, p. 25), with the protestant religious communities being the main agents and loci of socialization. In the case of the spirit of digital capitalism, the annual Burning Man event might play a similar role - one in which the solutionist beliefs of tech elites and workers alike are reinforced in ritualistic practices and Durkheimian experiences of collective effervescence (cf. Beckert, 2016, p. 79). "As once, 100 years ago, churches translated Max Weber's protestant ethic into a lived experience for congregations of industrial workers, so today Burning Man transforms the ideals and social structures of bohemian art worlds, their very particular ways of being 'creative', into psychological, social and material resources for the workers of a new, supremely fluid world of post-industrial information work" (Turner, 2009, pp. 75-76).
} 
the civic and industrial polities lose ground. This strongly confirms Boltanski and Chiapello's argument that the values of flexibility and agility have started to partly replace the values of technical efficiency and planning, which had their heyday in the age of Fordism. Starting in the late 1980s, we find this shift to post-Fordist values reflected in capitalist discourse.

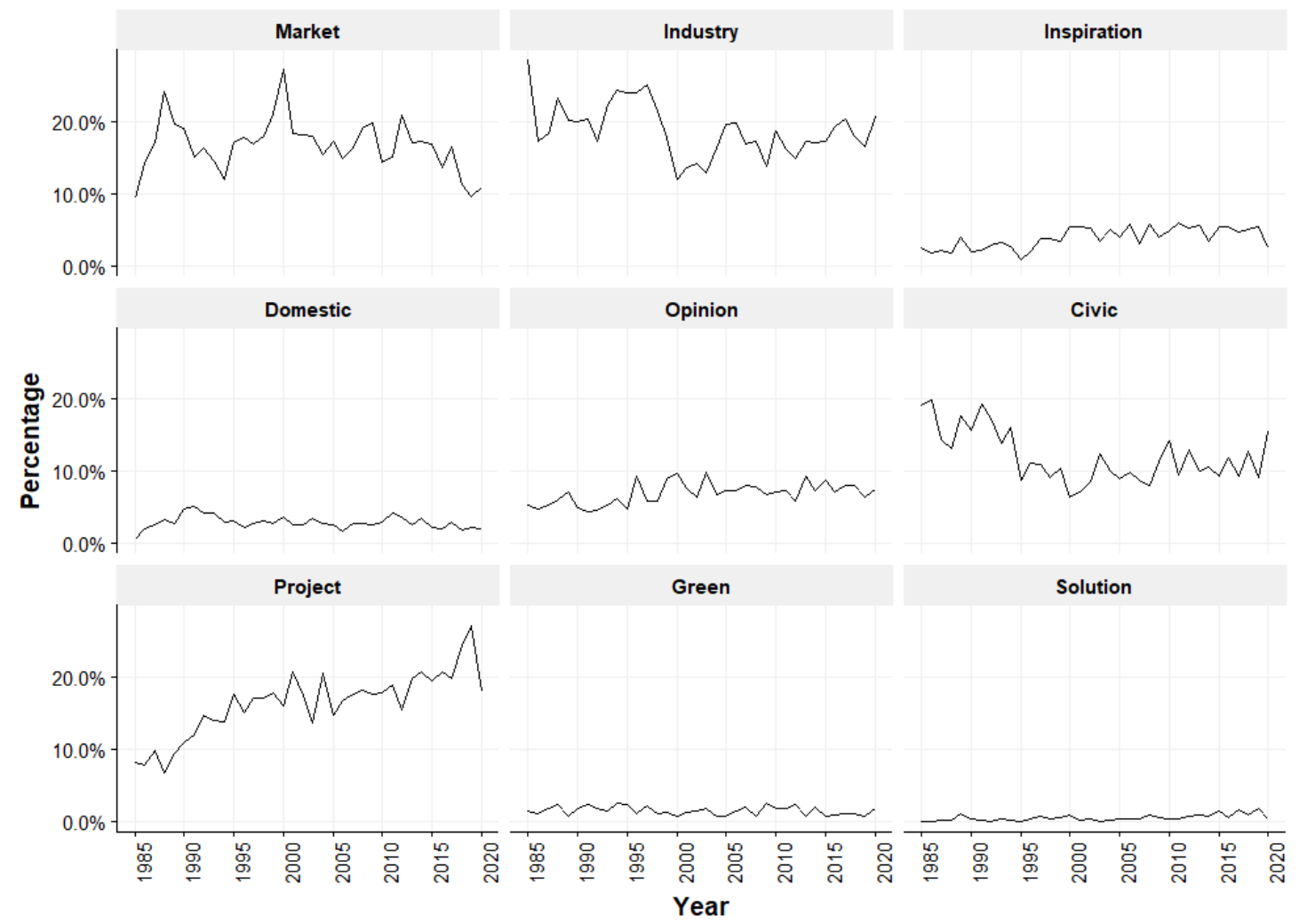

Figure 4: eferences to different polities in HBR articles (1985-2020)

The solutionist polity, meanwhile, remains marginal. Although we cannot be certain, it might have slightly grown in recent years, at about the same time when business scholars have rekindled a debate on the purpose of business. With much force, they have argued that businesses should abandon their narrow fixation on maximizing shareholder value and instead focus on creating "shared value" (Porter and Kramer, 2011) and "shareholder welfare" (Hart and Zingales, 2017) by "producing profitable solutions to problems of people and planet" (Mayer, 2018, p. 12). Even the Business Roundtable has recently moved away from the idea that the sole 
purpose of business is to increase shareholder value; instead, it encouraged companies to also invest in their employees, protect the environment and deal fairly with their suppliers (Gelles and Yaffe-Bellany, 2019). It remains to be seen to what extent ideas such as these serve as a bridgehead that allow solutionist values to enter the more mainstream debates on the values on which capitalist businesses should be build. For now, the new spirit of capitalism is still the dominant configuration of normative principles that justify capitalist action. But in the cultural crucible of Silicon Valley, a new spirit has been forged that already dominates the most important sector of our times, and, with the digitalization of economies and societies at large, is destined to become a central normative force legitimizing, motivating and orienting entrepreneurs and workers from all walks of capitalist life.

\section{Conclusion}

In this article, we have revisited and revised the concept of the capitalist spirit. Using both qualitative and quantitative evidence, we have shown how a new capitalist spirit has formed in the beating heart of contemporary capitalism: the tech sector. We have shown that the solutionist ethic - the belief that there is a profitable technological solution to every social problem - is wide-spread among tech elites and the wider tech milieu. We have not found a similar trend for capitalist discourse at large. This, however, might be due to a similar time lag as in the case of the projective polity, which, while having originated in the late 1960 s, only really gained momentum in the late 1980s. We have also theorized and illustrated how solutionist ideas have legitimized tech companies before policymakers and the public, helped them motivate their employees, and oriented their business decisions in the face of uncertainty.

We have thus contributed - conceptually, theoretically, and empirically - to the budding debate on the moral and ideational embedded of capitalism. In particular, 
we have shown how the normative orders of justification embodied in the spirit of capitalism shape the moral background against which capitalism is justified (Abend, 2014); how we can 'measure' and trace the normative logics that underlie and undergird capitalist action (Boltanski and Chiapello, 2007; Granovetter, 2017) and through which different moral views of the market society are expressed (Fourcade and Healy, 2007); and how imagined futures - and the economic dynamism and promissory legitimacy they supply - are informed by and rooted in particular normative principles, such as those of solutionism (Beckert, 2016, 2019).

In addition to uncovering the 'newest' spirit of capitalism, we have also reproduced Boltanski and Chiapello's finding that a new spirit of capitalism - one that centers around post-Fordist notions of flexibility and project-based activity - has risen in the 1980s and still dominates capitalist discourse. However, given the dominance of solutionist ideas in the tech sector, and given the economic and cultural dominance of the tech sector itself, it is likely that the solutionist ethic will gradually develop the "moral and normative force" (Sennett, 2006, p. 10) to also justify capitalism at large. As the fourth industrial revolution unfolds, this fourth, solutionist spirit of capitalism might well come to shape how most companies justify their business models, attract and appeal to their employees, and decide on a course of action when no single course is obvious.

While solutionism provided a powerful normative defense of capitalism at a time when capitalists were increasingly criticized for producing, rather than solving social problems, its proponents have recently themselves come under criticism for producing all sorts of social problems themselves, from creating addiction to spreading misinformation. While this has somewhat dampened the appeal of solutionist ideas (see Figure 3), it would be a mistake to write solutionism off. First, as tech companies move into new sectors, they remain unabashedly solutionist. As late as 2019, Google and Apple promise to use their technological prowess to 'trans- 
form health care', 'improve outcomes' and 'save lives'. And Facebook advertises its newest crypto-currency as a tool to 'empower billions of people'.

Second, tech companies have developed a kind of second-order solutionism where they promise technological solutions to problems that their own technologies have created. Co-opting the criticism that they have hijacked people's minds with their addictive and distracting technologies, tech companies have developed technological fixes to these primary technological and business defects, such as apps that help users understand their habits and nudge them towards more healthy ones. In the case of Facebook's Time Well Spent Initiative, they even co-opted the slogan of their most prominent critics at the Center for Humane Technology. This superficial incorporation of "tech-humanist" ideas "may provide Silicon Valley with a way to protect that power from a growing public backlash - and even deepen it by uncovering new opportunities for profit-making" (Tarnoff and Weigel, 2018). These developments remind us that solutionist ideas may well continue to shape the course and character of the ongoing digital revolution - we therefore better understand what they are about. 


\section{References}

Abend, Gabriel (2014). The Moral Background: An Inquiry into the History of Business Ethics. Princeton: Princeton University Press.

Bach, David and Daniel J. Blake (2016). "Frame or Get Framed: The Critical Role of Issue Framing in Nonmarket Management". In: California Management Review 58.3 , pp. $66-87$.

Barbrook, Richard and Andy Cameron (1996). "The Californian Ideology". In: Science as Culture 6.1, pp. 44-72.

Beckert, Jens (2016). Imagined Futures: Fictional Expectations and Capitalist Dynamics. Cambridge, Mass.: Harvard University Press.

- (2019). "The Exhausted Futures of Neoliberalism. From Promissory Legitimacy to Social Anomy". In: Journal of Cultural Economy, pp. 1-13.

Bewley, Truman F. (1999). Why wages don't fall during a recession. Cambridge: Harvard University Press.

Bezos, Jeff (2015). 2015 Letter to Shareholders. Available at: https : //ir . aboutamazon . com/static-files/f124548c-5d0b-41a6-a670-d85bb191fcec.

Blasio, Bill de (16.09.2019). NYC Mayor Bill de Blasio on why tech can't solve all our problems, and how New York lost Amazon HQ2. Available at: https : //soundcloud.com/recode-decode/nyc-mayor-bill-de-blasio-on.

Boltanski, Luc and Ève Chiapello (2007). The new spirit of capitalism. London: Verso.

Boltanski, Luc and Laurent Thévenot (2006). On Justification: Economies of Worth. Princeton: Princeton University Press.

Bowles, Nellie (2018). 'I Don't Really Want to Work for Facebook.' So Say Some Computer Science Students. Available at: https://www .nytimes .com/2018/11/ 15/technology/jobs-facebook-computer-science-students.html.

Bridle, James (2018). New dark age: Technology, knowledge and the end of the future. London and Brooklyn NY: Verso. 
Bröckling, Ulrich (2016). The Entrepreneurial Self: Fabricating a New Type of Subject. Los Angeles: Sage.

Broussard, Meredith (2018). Artificial Unintelligence: How Computers Misunderstand the World.

Campbell, Colin (2018). The romantic ethic and the spirit of modern consumerism. New extended edition. Cultural sociology. Cham, Switzerland: Palgrave Macmillan.

Castells, Manuel (2010). The Rise of the Network Society: The Information Age: Economy, Society, and Culture Volume I: Second Edition with a new Preface. Wiley-Blackwell.

CBS News (2014). Man behind Google Glass puts new twist on education. Available at: https : //www . cbsnews . com/news/google-glass-sebastian-thrun-onnewest-project-udacity/.

Diamandis, Peter (2020). How to become a Billionaire. Available at: https://www. diamandis.com/blog/how-to-become-a-billionaire.

Dickel, Sascha and Jan-Felix Schrape (2017). "The Logic of Digital Utopianism". In: Nanoethics 11.1, pp. 47-58.

Dror, Yuval (2015). “We are not here for the money': Founders' manifestos". In: New Media ES Society 17.4, pp. 540-555.

Etzioni, Amitai (1975). A comparative analysis of complex organizations: On power, involvement, and their correlates. Rev. and enl. ed. New York: Free Press.

Fisher, Eran (2010). "Contemporary Technology Discourse and the Legitimation of Capitalism". In: European Journal of Social Theory 13.2, pp. 229-252.

Foroohar, Rana (2019). Don't be Evil: How Big Tech Betrayed its Founding Principles - And All of Us. New York: Currency.

Fourcade, Marion and Kieran Healy (2007). "Moral Views of Market Society". In: Annual Review of Sociology 33.1, pp. 285-311. 
Friend, Tad (2015). Who Funds the Future? Available at: https://www . newyorker . com/magazine/2015/05/18/tomorrows-advance-man.

Gelles, David and David Yaffe-Bellany (2019). Shareholder Value Is No Longer Everything, Top C.E.O.s Say. Available at: https://www.nytimes.com/2019/08/ 19/business/business-roundtable-ceos-corporations.html.

Giridharadas, Anand (2018). Winners take all: The elite charade of changing the world. New York: Knopf.

Goldberg, Emma (2020). 'Techlash' Hits College Campuses. Available at: https: //www.nytimes.com/2020/01/11/style/college-tech-recruiting.html.

Granovetter, Mark (2017). Society and Economy: Framework and Principles. Cambridge, Mass.: Harvard Univ. Press.

Grimmer, Justin and Brandon M. Stewart (2013). "Text as Data: The Promise and Pitfalls of Automatic Content Analysis Methods for Political Texts". In: Political Analysis 21.03, pp. 267-297.

Habermas, Jürgen (1988). Legitimation Crisis. Cambridge: Polity Press.

Hart, Oliver and Luigi Zingales (2017). "Companies Should Maximize Shareholder Welfare Not Market Value". In: Journal of Law, Finance, and Accounting 2.2, pp. $247-275$.

Hopkins, Daniel J. and Gary King (2010). "A Method of Automated Nonparametric Content Analysis for Social Science". In: American Journal of Political Science 54.1, pp. 229-247.

Hull, Dana (2014). QESA with SunPower CEO Tom Werner, on solar's next big thing. Available at: https://www.siliconvalley.com/2014/05/16/2014-qawith-sunpower-ceo-tom-werner-on-solars-next-big-thing/.

Jerzak, Connor T., Gary King, and Anton Strezhnev (2019). An Improved Method of Automated Nonparametric Content Analysis for Social Science. Available at: https://gking.harvard.edu/files/gking/files/word.pdf. 
Johnston, Sean F. (2017). "Technological parables and iconic illustrations: American technocracy and the rhetoric of the technological fix". In: History and Technology 33.2, pp. 196-219.

Judge, Timothy A. and John D. Kammeyer-Mueller (2012). "Job attitudes". In: Annual review of psychology 63, pp. 341-367.

Marantz, Andrew (2016). How "Silicon Valley" Nails Silicon Valley. Available at: https://www . newyorker . com/culture/culture-desk/how-silicon-valleynails-silicon-valley.

Mayer, Colin P. (2018). Prosperity: Better business makes the greater good. Oxford: Oxford University Press.

McGoey, Linsey (2012). "Philanthrocapitalism and its critics". In: Poetics 40.2, pp. 185-199.

Mcnamee, Roger (2019). Zucked: Waking up to the Facebook Catastrophe. Penguin Books.

Morozov, Evgeny (2013). To Save Everything, Click Here: Technology, Solutionism and the Urge to Fix Problems that Don't Exist. New York: Public Affairs.

Nachtwey, Oliver and Timo Seidl (2017). Die Ethik der Solution und der Geist des digitalen Kapitalismus. Available at: http://www.ifs.uni-frankfurt.de/wpcontent/uploads/IfS-WP-11.pdf.

O'Toole, James (2019). The Enlightened Capitalists: Cautionary tales of business pioneers who tried to do well by doing good. New York NY.

Olma, Sebastian (2016). Digital Taylorism: Labour between Passion 8 Serendipity. Available at: https : //networkcultures .org/sebastianolma/2016/12/23/ digital-taylorism-labour-between-passion-serendipity/.

Porter, Michael E. and Mark R. Kramer (2011). "Creating Shared Value". In: Harvard Business Review January-February, pp. 1-17.

Schlosser, Kurt (2019). Review: Netflix documentary on Bill Gates reveals chaos, determination and love 'Inside Bill's Brain'. Available at: https://www.geekwire. 
com / 2019 / review - netflix - documentary - bill - gates - reveals - chaos determination-love-inside-bills-brain/.

Schmidt, Eric and Jared Cohen (2013). The New Digital Age: Reshaping the Future of People, Nations and Business. New York: Knopf.

Schröder, Martin (2013). "How Moral Arguments Influence Economic Decisions and Organizational Legitimacy - the Case of Offshoring Production". In: Organization 20.4 , pp. $551-576$.

Schulz, Thomas (2014). "Larry und die Mondfahrer". In: Der Spiegel 10.

Sennett, Richard (2006). The Culture of the New Capitalism. New Haven: Yale Univ. Press.

Serwer, Andy (2008). Larry Page on how to Change the World. Available at: https: //money.cnn.com/2008/04/29/magazines/fortune/larry_page_change_the_ world.fortune/index.htm.

Shane, Scott and Daisuke Wakabayashi (2018). The Business of War': Google Employees Protest Work for the Pentagon. Available at: https : //www . nytimes . com/2018/04/04/technology/google-letter-ceo-pentagon-project.html.

Slee, Tom (2016). What's Yours is Mine: Against the Sharing Economy. New York and London: OR Books.

Sombart, Werner (1902). Der Moderne Kapitalismus. Leipzig: Duncker \& Humblot. Stanley, Alessandra (2015). Silicon Valley's New Philanthropy. Available at: http:// WWw. nytimes.com/2015/11/01/opinion/siliconvalleys-new-philanthropy . html?_r=0.

Tacy, Chris (2011). What was Silicon Valley like after the bubble burst in the early 2000s? Available at: https : //www . quora . com/What-was-Silicon-Valleylike-after-the-bubble-burst-in-the-early-2000s.

Tarnoff, Ben (2018). Tech Workers Versus the Pentagon: An Interview with Kim. Available at: https : / / jacobinmag . com/2018/06/google-project-mavenmilitary-tech-workers/. 
Tarnoff, Ben and Moira Weigel (2018). Why Silicon Valley can't fix itself. Available at: https://www. theguardian.com/news/2018/may/03/why-silicon-valleycant-fix-itself-tech-humanism.

Taylor, Bill (1994). Control in the Age of Chaos. Available at: https://hbr.org/ 1994/11/control-in-an-age-of-chaos.

- (2016). The Best Entrepreneurs Are Missionaries, Not Mercenaries. Available at: https://hbr.org/2016/04/what-separates-high-impact-entrepreneursfrom-those-who-dont-make-a-big-difference.

The Economist (2018). How to Tame the Tech Titans. Available at: https://www . economist.com/leaders/2018/01/18/how-to-tame-the-tech-titans.

Thompson, Clive (2019). Coders: The Making of a New Tribe and the Remaking of the World. New York: Penguin Press.

Thompson, Derek (2017). Google X and the Science of Radical Creativity. Available at: https : //www . theatlantic . com/magazine/archive/2017/11/x-googlemoonshot-factory/540648/.

Thompson, Nicholas and Fred Vogelstein (2018). Inside the Two Years That Shook Facebook - and the World. Available at: https : / / www . wired . com/story / inside-facebook-mark-zuckerberg-2-years-of-hell/.

Tiku, Nitasha (2019). Three Years of Misery Inside Google, the Happiest Company in Tech. Available at: https://www.wired.com/story/inside-google-threeyears-misery-happiest-company-tech/.

Turner, Fred (2006). From Counterculture to Cyberculture: Stewart Brand, the Whole Earth Network, and the Rise of Digital Utopianism. Chicago: University of Chicago Press.

- (2009). "Burning Man at Google: A cultural infrastructure for new media production". In: New Media \& Society 11.1-2, pp. 73-94.

- (2017). Don't Be Evil: Fred Turner on Utopias, Frontiers, and Brogrammers. Available at: https://logicmag.io/justice/fred-turner-dont-be-evil/. 
Uzunca, Bilgehan, J. P. Coen Rigtering, and Pinar Ozcan (2018). "Sharing and Shaping: A Cross-Country Comparison of How Sharing Economy Firms Shape Their Institutional Environment to Gain Legitimacy". In: Academy of Management Discoveries 4.3, pp. 248-272.

Weber, Max (1946). "The Social Psychology of the World Religions". In: From Max Weber: Essays in Sociology. Ed. by H. H. Gerth and C. Wright Mills. New York: Oxford University Press, pp. 267-301.

- (2001). "Weber's Second Reply to Karl Fischer, 1908: From the Archiv für Sozialwissenschaft und Sozialpolitik, vol. 26, pp. 275-83". In: The Protestant ethic debate. Ed. by Austin Harrington, David J. Chalcraft, and Mary Shields. Liverpool: Liverpool University Press, pp. 43-51.

- (2007). The Protestant Ethic and the Spirit of Capitalism: Translated by Talcott Parsons. With an Introduction by Anthony Giddens. London: Routledge.

Weigel, Moira and Ben Tarnoff (2019). The Stark Political Divide Between Tech CEOs and Their Employees. Available at: https://newrepublic.com/article/ 153046/stark-political-divide-tech-ceos-employees.

Weizenbaum, Joseph (1976). Computer Power and Human Reason: From Judgment to Calculation. San Francisco: Freeman.

Yeritsian, Gary (2018). “Capitalism 2.0': Web 2.0 Manifestoes and the New Spirit of Capitalism". In: Critical Sociology 44.4-5, pp. 703-717.

Žižek, Slavoj (2006). Nobody has to be vile. Available at: https://www.lrb.co.uk/ v28/n07/slavoj-zizek/nobody-has-to-be-vile.

Zuboff, Shoshana (2019). The Age of Surveillance Capitalism: The Fight for a Human Future at the New Frontier of Power. Public Affairs. 


\section{Appendices}

\section{A. Data Collection \& Sampling}

In the following subsections, we provide more detail on the three corpora used in the paper.

\section{A.1. Digital Elites Corpus}

Compiling the elites corpus - a corpus of interviews, speeches, self-descriptions by the most recent generation of digital elites - involved three steps. First, we used to 2015 Forbes 400 list to identify the most successful (i.e., richest) tech elites, selecting those that made their money with digital technologies, be it as entrepreneurs (e.g. Larry Page, Elon Musk), high level executives (e.g. Eric Schmidt, Sundar Pichai) or as some mixture of entrepreneur and venture capitalists (e.g. Peter Thiel, Reid Hoffmann). Second, we selected those on that list that started what made them rich in the second half of the 1990s or later, the argument being that this newest generation of mainly web-based entrepreneurs should be quite different - both age-wise and with regard to the kinds of companies they built - from an earlier generation of mainly PC-based entrepreneurs like Steve Jobs or Bill Gates (O'Reilly, 2017). Finally, we manually searched for recent documents in which these individuals describe their motivation or make programmatic statements from which their broader beliefs - as opposed to their technical knowledge, etc. - are evident. This sampling procedure resulted in 90 documents - all dating from between 2009 and 2018 - which were then split into 2326 paragraphs. Table 2 depicts the individuals that make up the digital elites corpus as well as how many documents from each individual were included. 
Table 2: List of digital elites (based on Forbes 400) with number of documents

\begin{tabular}{|c|c|}
\hline Name & Number of Documents \\
\hline Bob Parsons & \\
\hline Brian Acton & \\
\hline Brian Chesky & \\
\hline Dustin Moskovitz & \\
\hline Elon Musk & \\
\hline Eric Schmidt & 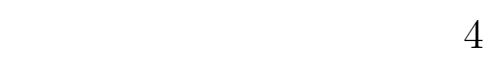 \\
\hline Evan Spiegel & \\
\hline Evan Williams & \\
\hline Gabe Newell & \\
\hline Jack Dorsey & \\
\hline Jan Koum & \\
\hline Jeffrey Skoll & \\
\hline Jerry Yang & \\
\hline Joe Gebbia & \\
\hline Larry Page & \\
\hline Marc Benioff & \\
\hline Mark Zuckerberg & \\
\hline Michael Rubin & \\
\hline Nathan Blecharczyk & \\
\hline Nick Woodman & \\
\hline Peter Thiel & \\
\hline Pierre Omidyar & \\
\hline Reid Hoffman & \\
\hline Robert Pera & \\
\hline Sean Parker & \\
\hline
\end{tabular}


Sergey Brin 3

Sundar Pichai 3

Travis Kalanick 3

Overall $\quad 90$

\section{A.2. Wired Corpus}

We scraped the Wired corpus from the web and - after manually inspecting the data - we are reasonably confident to have acquired if not all than most articles published in Wired between the magazine's founding in 1993 and 2019. We again split all articles into paragraphs - our unit of analysis. We then removed very short paragraphs with less than 200 characters as they often contain no useful information. As a result, we ended up with 1.514 .839 paragraphs.

\section{A.3. Harvard Business Review Corpus}

We also scraped the Harvard Business Review corpus from the web. With an automated script, we first generated the article-links and then downloaded the text from the website. As the texts were already divided into paragraphs in the HTMLsource, we were able to extract the articles fairly easy. However, we realized that the articles we obtained via our library's access provider were incomplete as not all articles are available as HTML. We were thus far unable to retrieve to retrieve all documents or to reliably extract paragraphs from documents that are only available as column-separated PDF files. Figure 5 depicts the HBR articles that are available as HTML files (red) versus all available articles (black) on EBSCO Host. To avoid bias, we restricted our analysis - for the moment - to all years after 1985, where were able to acquire not all but most articles. This procedure resulted in 161.204 paragraphs. 


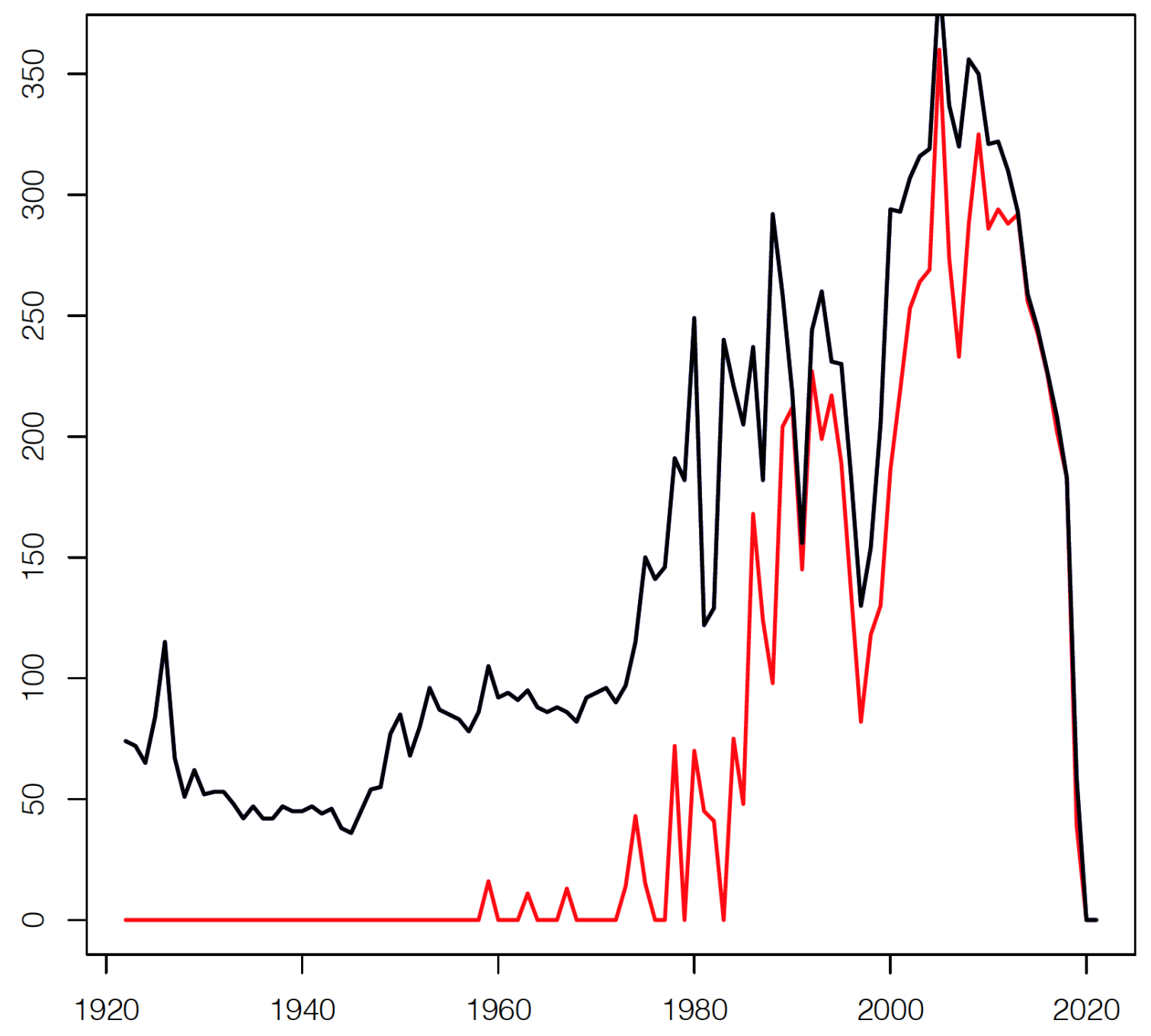

Figure 5: HBR articles available as HTML files (red) versus all available (black) articles 


\section{B. Intercoder Reliability}

After training the coders and refining the coding scheme, we randomly sampled 1518 paragraphs with roughly equal numbers from the three corpora: 398 for the elite corpus, 591 from the Wired Corpus, 529 from the Harvard Business Review Corpus. Table 3 reports various measures of intercoder reliability, plus bootstrapped confidence intervals when available. ?? depicts a confusion matrix showing that many disagreements resulted from one coder choosing "Other" while the other code chose one of the polities. As reported in the paper, if we remove these disagreements, reliability scores further improve, as reported in Table 5.

Table 3: Intercoder Reliabiltiy Metrics

\begin{tabular}{lcc}
\hline Measure & Value & $\mathbf{9 5 \%}$ Confidence Interval \\
\hline Krippendorff's Alpha & 0.697 & $0.68-0.71$ \\
Cohen's Kappa & 0.697 & $0.67-0.73$ \\
Gwet's AC1 & 0.747 & $0.72-0.77$ \\
Holsti's Method (Percentage Agreement) & 0.769 & -
\end{tabular}




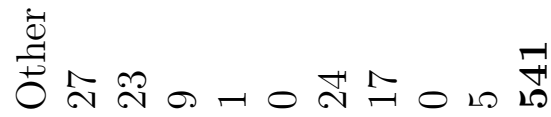

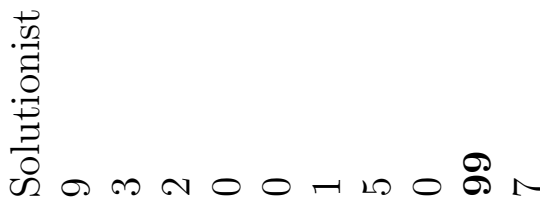

U⿺辶寸

$\frac{+}{0}$

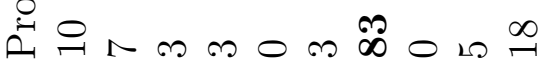

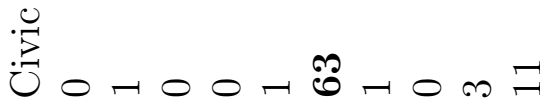
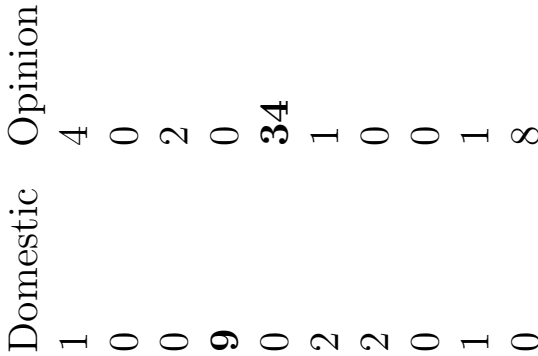

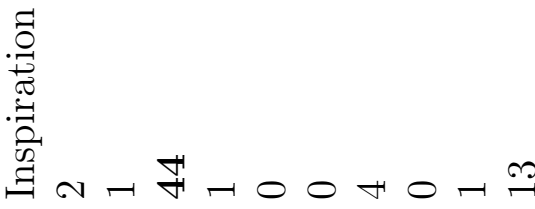

$\stackrel{\overrightarrow{0}}{3}$

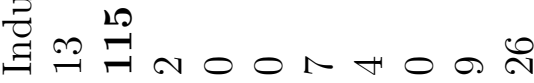

$\underset{4}{4}$

寄

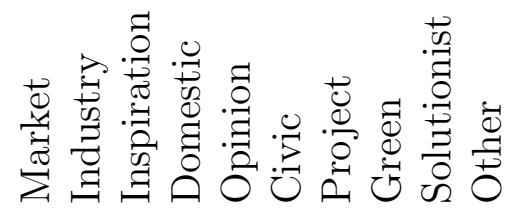


Table 5: Intercoder Reliabiltiy Metrics

\begin{tabular}{lcc}
\hline Measure & Value & $\mathbf{9 5 \%}$ Confidence Interval \\
\hline Krippendorff's Alpha & 0.868 & $0.86-0.87$ \\
Cohen's Kappa & 0.868 & $0.85-0.89$ \\
Gwet's AC1 & 0.889 & $0.87-0.91$ \\
Holsti's Method (Percentage Agreement) & 0.898 & -
\end{tabular}

\section{With and Without Validation}

This section compares the results of readme2 depending on whether or not we remove unmatched word stems. It shows that remain roughly similar and none of the differences affects our substantive interpretations.

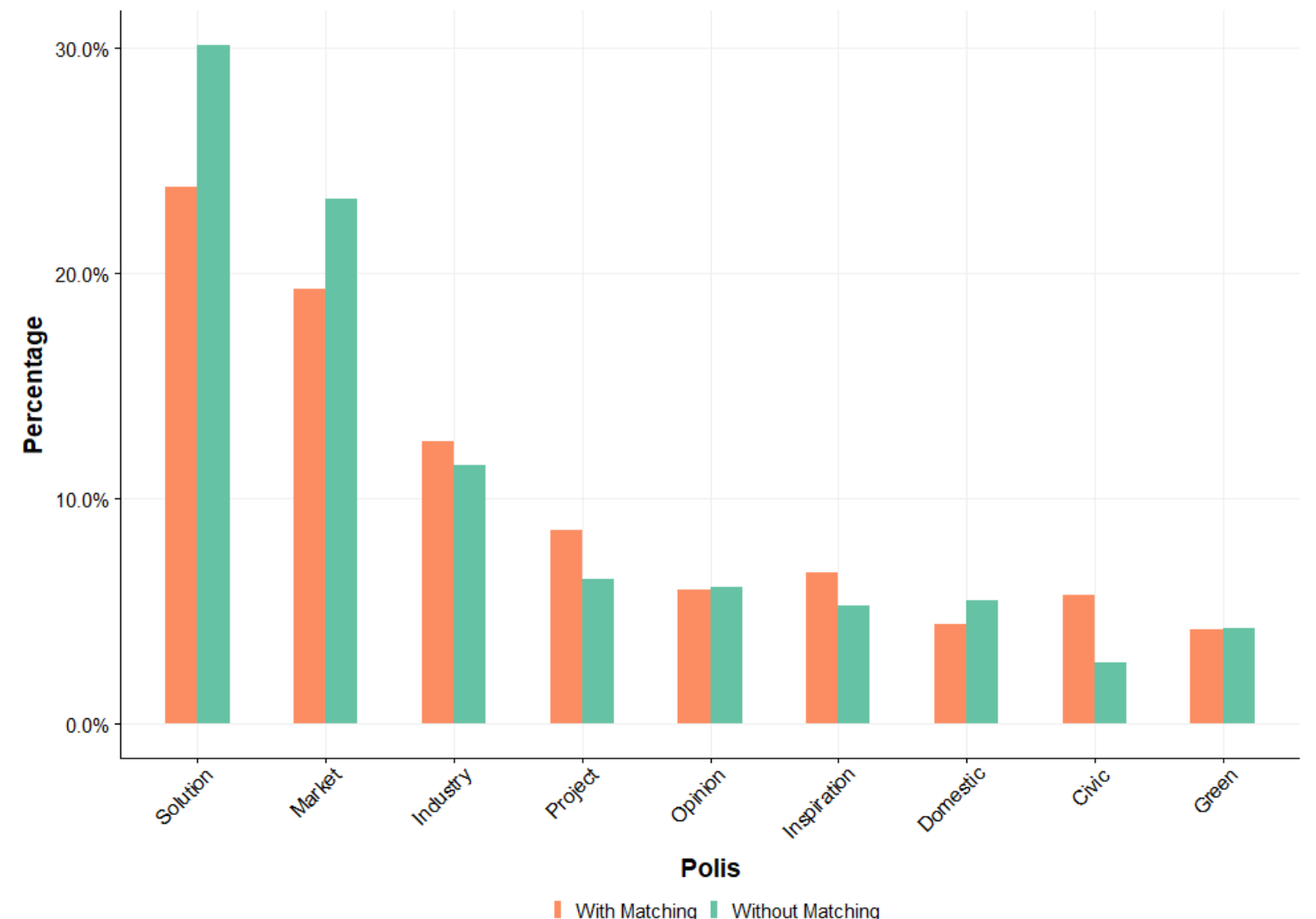

Figure 6: Elites with and without matching 


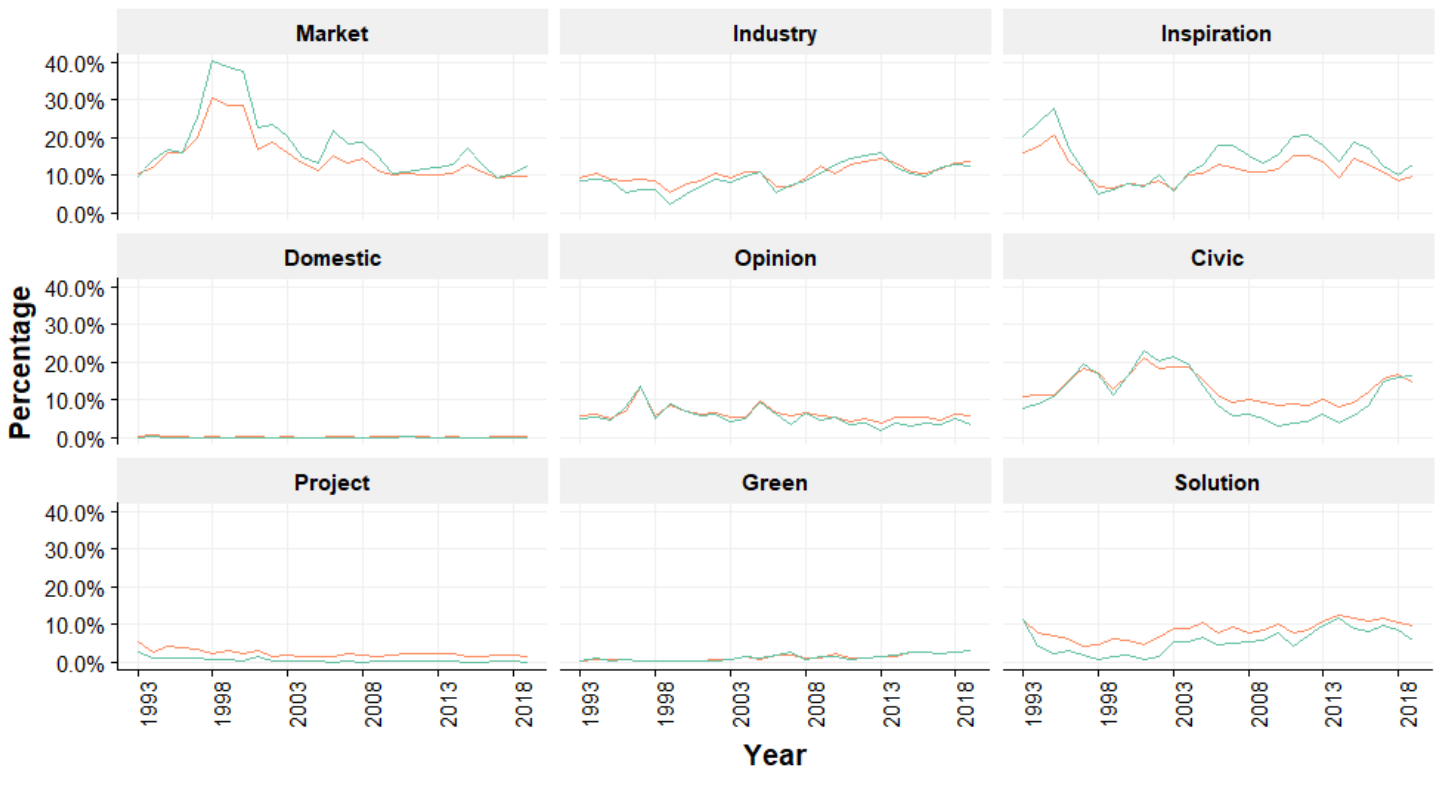

With Matching - Without Matching

Figure 7: Wired with and without matching

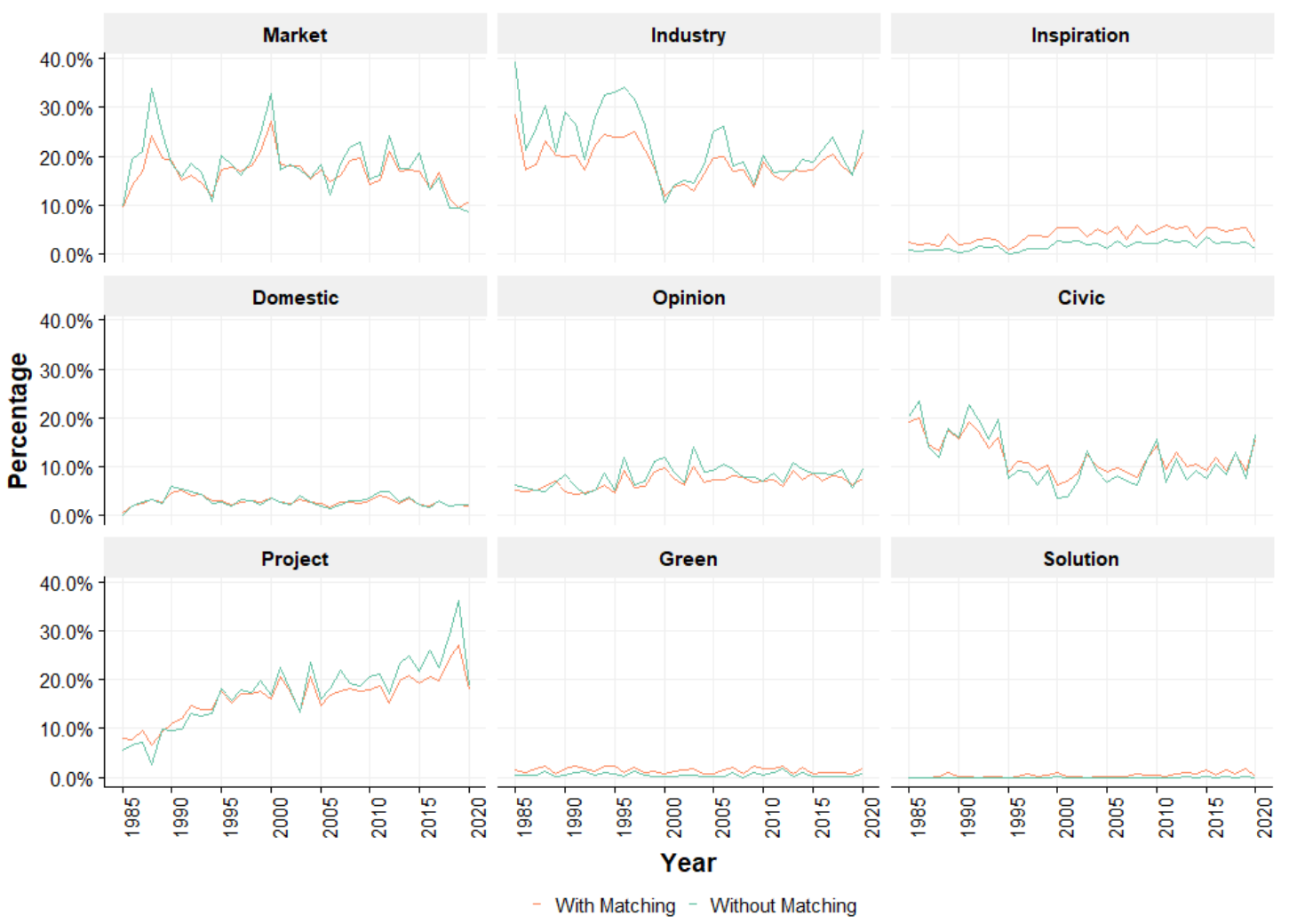

Figure 8: Harvard Business Review with and without matching 


\section{References}

O'Reilly, Tim (2017). WTF: What's the future and why it's up to us. New York, NY: Harper Business. 